\title{
La constitucionalización del derecho procesaly su repercusión en la reforma de la normatividad ritual (CPP)* y el sistema de justicia penal
}

\section{Constitutionalization of arbitration and its impact in standard legislation reform, CPP (Criminal Procedure Code) and in criminal justice system}

\section{MARIO PABLO RODRÍGUEZ HURTADO**}

Resumen: Este artículo reflexiona sobre la estrecha relación entre el proceso penal y el derecho constitucional en el marco de un Estado democrático, así como sobre las garantías que debe brindar desde la óptica constitucional y en el actual contexto de globalización de los derechos humanos. A continuación nos aproxima a los principales principios y garantías del proceso penal, y a los modelos procesales históricamente configurados. Finalmente, el artículo nos presenta un interesante análisis de Código Procesal Penal, describiendo las garantías, principios y modelo procesal reconocido de nuestro país.

Palabras clave: derecho procesal penal - sistema de justicia penal - garantías procesales - Código Procesal Penal

Summary: This article examines the close relationship between criminal procedure and constitutional law within a democratic State framework as well as the guarantees provided from a constitutional point of view in accordance with the current context of human rights globalization. Then, the author approaches us to criminal procedure main principles and guarantees, procedural models historically formed. Finally, it presents an interesting Criminal Procedural Code analysis describing guarantees, principles and procedural models recognized in our country.

Key words: criminal procedural law - criminal justice system - procedural guarantees, Criminal Procedural Code

Código Procesal Penal (D. Leg. 957), publicado el 29 de julio de 2004 en el diario oficial El Peruano. Ver: http://spij.minjus.gob.pe/CLP/contenidos.dIl?f=templates\&fn=default-nuevocodprocpenal. htm\&vid=Ciclope:CLPdemo

* Profesor de Derecho Penal, Derecho Procesal Penal y Litigación Oral UNMSM - PUCP - AMAG. Abogado, Reg. CAL 9019. Correos electrónicos: maparo@amauta.rcp.net.pe, mprodrig@ pucp.edu.pe 
CONTENIDO: I. PROGRAMA PROCESAL PENAL DE LA CONSTITUCIÓN.I.1. DERECHO PROCESAL PENAL Y DERECHO CONSTITUCIONAL.- I.2. RÉGIMEN DEMOCRÁTICOY PROCESO PENAL.- I.3. TRATADOS INTERNACIONALES SOBRE DERECHOS HUMANOS Y DERECHO PROCESAL PENAL.- I.4. GARANTÍAS PROCESALES O ESCUDOS PROTECTORES DEL JUSTICIABLE. LA POSTURA DEL PROFESOR ALBERTO BINDER, PROPULSOR DE LA REFORMA EN AMÉRICA LATINA.- I.4.1. PREVALENCIA DE LA NORMA CONSTITUCIONAL.I.4.2. POTESTAD JURISDICCIONAL POPULAR Y PODER JUDICIAL.I.4.3. IRRETROACTIVIDAD DE LA LEY.- I.4.4. DEBIDO PROCESO Y TUTELA JURISDICCIONAL.- I.4.5. JUICIO PREVIO Y PRESUNCIÓN DE INOCENCIA.I.4.6. GARANTÍAS QUE EVITAN LA MANIPULACIÓN DEL PROCESO.I.4.7. ARANTÍAS QUE RESTRINGEN LA POTESTAD ESTATAL DE BÚSQUEDA DE INFORMACIÓN PROBATORIA.- I.4.8. GARANTÍAS QUE LIMITAN EL USO DE LA FUERZA (COERCIÓN) EN EL PROCESO.- II. SERVICIO DE JUSTICIA Y SUCESIÓN Y PUGNA DE MODELOS PROCESALES.- II.1. INQUISITORIAL.- II.2. MIXTO.II.3. ACUSATORIO ANTIGUO Y CONTEMPORÁNEO.- III. PANORAMA DEL TÍTULO PRELIMINAR DEL CPP.- III.1. OPCIÓN ACUSATORIA, GARANTIZADORA, DE TENDENCIA ADVERSATIVA, EFICAZ Y EFICIENTE.- III.2. PRINCIPIOS ACOGIDOS.- III.3. PRINCIPIOS Y PROBLEMAS DE IMPLEMENTACIÓN Y REGENCIA PROGRESIVAS DEL CPP.

\section{PROGRAMA PROCESAL PENAL DE LA CONSTITUCIÓN} En este capítulo se sostiene que el proceso penal no es un atado informe de trámites o anárquico deambular de secuencias, sino un mecanismo de resolución de conflictos ocasionados por los delitos, un escenario que se pone al servicio de la colectividad, las víctimas y los procesados.

El mecanismo procesal, desde la orilla constitucional, asume orientación, principios, modelo y vigas maestras; es más, la Carta Política y de Derechos deja en él impronta inocultable. Por eso es que el proceso penal de un Estado democrático no puede menos que adherir esa opción, contemporáneamente robustecida por la globalización de los derechos humanos y la vigencia de los tratados internacionales sobre la materia.

Reconociéndose que la fortuna del proceso penal depende del equilibrio que alcance entre los extremos en permanente tensión que atiende: la seguridad y eficacia ante el delito para restablecer la paz y tranquilidad por un lado, y las garantías o derechos fundamentales del incriminado por el otro, es menester nunca perder de vista o postergar los escudos protectores del justiciable que repudian la arbitrariedad y evitan que el drama procesal pierda su perfil democrático. 


\section{I.1. Derecho procesal penal y derecho constitucional}

Para contestar qué es o cómo se define el proceso penal existen dos criterios: el primero, tradicional, propio del estamento burocrático, señala que es una sucesión de etapas o actividades — esto es, trámites - cuyo conocimiento y manejo deviene de la práctica cotidiana, encaminados a concretar las consecuencias de la norma penal sustantiva. La otra postura afirma, en cambio, que el proceso penal no se agota con la manifestación superficial de su secuencia y trámites sino que es un mecanismo de resolución o redefinición de conflictos surgidos en la sociedad por el acaecimiento de un hecho delictuoso, pues interesa a la víctima y a la sociedad que se supere $-\mathrm{O}$, por lo menos, reduzca- el nivel de violencia u ofensa que subyace en cualquier evento punible, lesivo o riesgoso para bienes jurídicos de primer orden ${ }^{1}$.

Desde esta última óptica, el proceso no puede organizarse de cualquier manera, ya que repeler el delito y asegurar la tranquilidad, seguridad y paz de los ciudadanos —obligación estatal que debe atenderse eficaz y eficientemente- no implica arrasar o desconocer los derechos fundamentales de los imputados, quienes, pese a estar procesados, no dejan de ser personas ni carecen de dignidad.

Se aprecia, entonces, que el proceso penal se ocupa de asuntos de envergadura mayor, recogidos no solo en leyes o normas ordinarias, sino pautados en la Constitución ${ }^{2}$. Así, el artículo 44 de la Carta Política estipula que es deber primordial del Estado garantizar la plena vigencia de los derechos humanos, proteger a la población de las amenazas contra su seguridad y promover el bienestar general que se fundamenta en la justicia y el desarrollo. Nadie negará que el delito constituye una de esas amenazas a la seguridad y que, por ello, el Estado debe estructurar y poner en marcha un mecanismo que lo afronte, sin que esa preocupación por la seguridad faculte desechar los derechos fundamentales del justiciable, según lo prevé el amplio artículo 2 de la Suprema Ley.

La organización del proceso penal reclama cuidadoso equilibrio entre dos extremos en permanente tensión: la obligación y potestad del Estado de perseguir el delito y sancionar a sus autores, por un lado, y el respeto de los derechos y garantías de los incriminados, por el otro. Roto este equilibrio, se arruinan los elevados objetivos del proceso penal. Sobredimensionar la persecución y la punición con argumentos de eficacia a ultranza conduce a la arbitrariedad; extremar las garantías —o hasta desnaturalizarlas_ deja impotente al sistema.

LA CONSTITU-

CIONALIZACIÓN

DEL DERECHO

PROCESAL Y SU

REPERCUSIÓN EN

LA REFORMA DE

LA NORMATIVIDAD

RITUAL (CPP) Y EL

SISTEMA DE

JUSTICIA PENAL

CONSTITUTIO-

NALIZATION OF

ARBITRATION AND

ITS IMPACT IN

STANDARD

LEGISLATION

REFORM, CPP

(CRIMINAL

PROCEDURE

CODE) AND IN

CRIMINAL JUSTICE

SYSTEM 
Como en todo proceso penal se airean asuntos de mucha importancia: paz, tranquilidad, seguridad y derechos fundamentales, esencialmente, y la libertad personal. Las normas jurídicas que lo regulan no pueden dictarse de espaldas a la Constitución, que cuenta con un programa procesal penal que establece la orientación, el espíritu, modelo y las vigas maestras del mecanismo oficial de resolución de conflictos jurídicopenales relevantes.

Un recorrido de la Constitución confirma lo dicho acerca de este programa, que proyecta un cierto tipo de proceso y no cualquier suma de etapas y trámites. Como se adelantó, al Estado le compete perseguir y sancionar el delito, para lo cual se sirve del proceso penal (artículo 44). Este mecanismo al que son sometidos los imputados les reconoce derechos y garantías, como los recogidos en los artículos 2 y 139 de la Ley Fundamental. Asimismo, para que el proceso sea justo y transparente y que las decisiones que surgen de él no respondan a intereses subalternos o coyunturales, la Constitución estipula que la potestad de administrar justicia emana del pueblo y se ejerce por el Poder Judicial independiente (artículos 138y 139.2). Encarga la persecución del delito, su investigación, acusación y pruebas o acreditación de la pretensión punitiva estatal a un órgano civil autónomo: el Ministerio Público (artículo 159), apoyado por la Policía Nacional como brazo operativo (artículo 166). No olvida, tampoco, reconocer el derecho de defensa, facultado para descargar y desvirtuar las incriminaciones fiscales (139.14).

Es más, la Constitución, al remarcar la trascendencia de la actividad probatoria, estatuye como requisito primordial su legitimidad, de modo que para la Carta Política carecen de validez las pruebas obtenidas con violación de derechos fundamentales, según se infiere del artículo 2, incisos 10 y 24 literal $\mathrm{h}$, referido a las ofensas contra el secreto e inviolabilidad de las comunicaciones y documentos privados y a la tortura u otros tratos inhumanos o humillantes. En lo que atañe al empleo de la fuerza o coerción durante el proceso, la Suprema Ley aporta los parámetros que rigen su aplicación, esto son la razonabilidad y proporcionalidad previstas en el artículo 200. Los ingredientes para instituir un debido proceso penal, la configuración de su modelo, principios, objetivos, funciones y sujetos procesales básicos y la exigencia de legitimidad probatoria y cautelar ya vienen dados por la Constitución, correspondiendo a la normatividad ordinaria, como el CPP, su consecuente desarrollo.

Llevaba razón el viejo jurista alemán Jürgen Baumann cuando confirmaba el aserto de su colega Henkel en el sentido de que el derecho procesal penal es derecho constitucional aplicado 3 .

3 BAUMANN, Jürgen. Derecho procesal penal. Conceptos fundamentales y principios procesales. Introducción sobre la base de casos. Buenos Aires: Depalma, 1989, p. 29. 
Para no referir solo la doctrina alemana, hay que decir que el Perú ha confirmado dolorosamente el enorme perjuicio infligido al servicio de justicia penal y, desde luego, a los imputados y las víctimas, por el alejamiento y la infracción de cláusulas constitucionales perpetrados en la pasada década de 1990, como hacen notar las sentencias del Tribunal Constitucional emitidas en procesos interpuestos por el Defensor del Pueblo contra el paquete normativo de «seguridad nacional» (expediente 0005-2001-AI/TC, sentencia de 15 de noviembre de 2001), uno de cuyos componentes fue el decreto legislativo 897: «Procedimiento especial para delitos agravados», y por el ciudadano Marcelino Tineo Sulca y otros, contra el decreto ley 25659: «Traición a la Patria» en modalidad terrorista (expediente 010-2002-AI/TC, sentencia de 3 de enero de 2003) ${ }^{4}$. Estas infracciones constitucionales motivaron que centenares de sentencias y procedimientos se anulen y vuelva a procesar a los imputados de graves delitos.

El nexo entre derecho procesal penal y derecho constitucional no es, pues, una cuestión académica, una entelequia dogmática, sino un imperativo para el servicio de justicia y sus operadores.

\section{I.2. Régimen democrático y proceso penal}

El hecho de que el proceso penal reciba sus notas esenciales de la Constitución no es producto del azar o de la errática decisión del legislador, sino consecuencia inevitable de la opción del constituyente por un régimen republicano, democrático y de derecho.

Por eso es acertado repetir que el tipo de proceso penal con el que cuenta un país refleja el grado de desarrollo o no de su democracia y de respeto o violación de las libertades civiles 5 .

Un Estado que reconoce en su Constitución, en virtud del principio republicano, que los asuntos fundamentales que afectan el destino del país son de interés de todos los ciudadanos, que, en razón del principio democrático, reclama la activa y plural participación de aquellos, y que tanto gobernantes como gobernados se encuentran sometidos por igual

4 Ver: http://www.tc.gob.pe/jurisprudencia/2001/00005-2001-Al.html

http://www.tc.gob.pe/jurisprudencia/2003/00010-2002-Al.html

Estos pronunciamientos recibieron el positivo influjo de sentencias de la Corte Interamericana de Derechos Humanos, entre las cuales destacan las emitidas el 17 de setiembre de 1997 en los casos «Loayza Tamayo», 3 de noviembre del mismo año "Castillo Páez», y 30 de mayo de 1999 "Castillo Petruzzi».

Ver: http://www.corteidh.or.cr/bus_fechas_result.cfm?buscarPorFechas=Buscar\&fechaDelnicio=12 \%2F31\%2F1996\&fechaDeFin=04\%2F28\%2F2010\&id\%5FPais=8\&chkCasos=true\&chkOPiniones=f alse \&chkMedidas=false \&chkSupervisiones=false

http://www.corteidh.or.cr/docs/casos/articulos/seriec_33_esp.pdf http://www.corteidh.or.cr/docs/casos/articulos/seriec_34_esp.pdf http://www.corteidh.or.cr/docs/casos/articulos/seriec_52_esp.pdf

5 GoldSCHMIDT, James. Principios generales del proceso, II. Buenos Aires: EJEA, 1961, pp 109-110. PICó I JUNOY, Joan. Las garantías constitucionales del proceso. Barcelona: Bosch, 1997, p 11.

\section{LA CONSTITU- \\ CIONALIZACIÓN \\ DEL DERECHO \\ PROCESAL Y SU \\ REPERCUSIÓN EN \\ LA REFORMA DE \\ LA NORMATIVIDAD \\ RITUAL (CPP) Y EL \\ SISTEMA DE \\ JUSTICIA PENAL \\ CONSTITUTIO- \\ NALIZATION OF \\ ARBITRATION AND \\ ITS IMPACT IN \\ STANDARD \\ LEGISLATION \\ REFORM, CPP \\ (CRIMINAL \\ PROCEDURE \\ CODE) AND IN \\ CRIMINAL JUSTICE \\ SYSTEM}


ante la ley y el derecho, en obsequio del principio de igualdad (artículos $43,2.2 .17,31,45)$, no puede menos que instituir una política, también con estas cualidades, en el campo de la resolución de los conflictos ocasionados por la ocurrencia de los delitos.

Ninguno de los principios precitados es de reciente fábrica, pues ya los recogió la Constitución de 1979 (artículos 79, 2.2.16, 64, 81), lo que invita a preguntarse si en materia procesal penal se ha efectivizado la adecuación que reclaman tales imperativos. Uno de ellos, por ejemplo - el de la separación de poderes, la existencia de contrapesos y controles mutuos para evitar la arbitrariedad y el abuso- se refleja en el proceso penal en la determinación diferenciada de las funciones procesales básicas: persecución, defensa y enjuiciamiento - fallo, y en la asignación de cada una de ellas al respectivo sujeto procesal: Ministerio Público, imputado-defensor técnico y juez, como establecen, respectivamente, los artículos IV y 60, IX, 71 y 80, y V y 16 del CPP.

Ocurre, no obstante, que la adecuación normativa ritual según pautas constitucionales tuvo que esperar doce largos años luego de 1979: apareció por primera vez de modo nítido en el CPP de $1991^{6}$ (artículos V y 58 - Ministerio Público, VIII, 68 y 76 - imputado, defensor técnico, y I y 55 - órgano jurisdiccional), aunque sin traspasar la barrera de la vacatiolegis hacia la vigencia plena.

A contramano de lo esperado, hasta hoy la justicia penal peruana se presta bajo reglas incompatibles con los requerimientos constitucionales, de manera que la aplastante mayoría de causas aún sigue la vía procesal sumaria (decreto legislativo 124 y leyes 26689 y 27507) ${ }^{7}$, enemiga del juicio público y oral y apañadora de la fusión inaceptable, por afectar la imparcialidad objetiva, de las tareas de persecución - sobre todo la investigación del delito- con las de fallo, como si al juez que le correspondió pesquisar pudiese asignársele la labor de calificar, mediante sentencia, su propio trabajo y el del Ministerio Público acusador, dejando al imputado y la defensa en desigualdad y en inferioridad de condiciones. Así es como el proceso sumario abjura de los axiomas democráticos que indican que quien investiga no puede ser el mismo que falle y que todo acusado tiene derecho a que su situación se resuelva mediante juicio previo, público y oral.

Este nexo raigal entre Estado de derecho y democracia con proceso penal no está siempre debidamente asegurado, ni debe ser sobrentendido.

6 Decreto legislativo 638, publicado en el diario oficial El Peruano el 27 de abril de 1991.

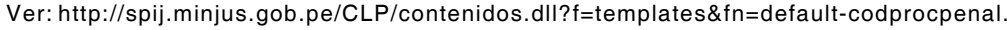
htm\&vid=Ciclope:CLPdemo

7 Ver: http://190.41.250.173/rij/bases/legisla/peru/pen49.htm http://www.congreso.gob.pe/ntley/Imagenes/Leyes/26689.pdf http://www.congreso.gob.pe/ntley/Imagenes/Leyes/27507.pdf 
Reclama, en cambio, celo, cuidado y operatividad constantes, pues bastaría que una administración gubernativa tenga suficiente poder para alterar las reglas básicas del juego constitucional, o poner en marcha la aplicación de leyes autoritarias, para que la maquinaria procesal penal se ensombrezca. Un ejemplo negativo de la manera como incluso encumbrados juristas sucumbieron ante corrientes antidemocráticas lo hallamos en las palabras del profesor alemán Edmundo Mezger, quien hacia 1933 no tuvo el menor empacho en sostener que:

El nuevo Estado totalitario se eleva apoyándose en los principios básicos de pueblo y raza. También el derecho punitivo habrá de ser afectado de modo profundo por esta transformación [...]. Para el nuevo derecho penal serán esenciales dos puntos de partida, pero no el sentido de una transacción, como hasta ahora, sino como síntesis más alta, a saber: el pensamiento de la responsabilidad del individuo ante su pueblo y el de la regeneración racial del pueblo como un todo [...]. El Estado totalitario exige de sus súbditos una conducta de firmeza frente a las múltiples tentaciones y estímulos exteriores de índole criminal. Exige tal conducta, ante todo, en circunstancias «normales», pero también en situaciones extraordinarias ${ }^{8}$.

No hay gran misterio ni complejidad tras la afirmación que dice que, mientras que un régimen democrático reconoce un proceso penal de igual categoría, uno autoritario y dictatorial se premune de un proceso penal abusivo, generalmente sustentado en el encarcelamiento.

\section{I.3. Tratados internacionales sobre derechos humanos y derecho procesal penal}

Interesa precisar que la renovación traída al proceso penal por la Constitución de 1979 tuvo su origen en importantes tratados internacionales, como la Declaración Universal de los Derechos Humanos $^{9}$, del 10 de diciembre de 1948, aprobada por resolución legislativa $13282^{10}$, del 9 de diciembre de 1959; el Pacto Internacional de Derechos Civiles y Políticos ${ }^{11}$, del 16 de diciembre de 1966, aprobado por decreto ley $22128^{12}$; del 28 de marzo de 1978, y la Convención Americana sobre Derechos Humanos ${ }^{13}$, del 22 de noviembre de 1969, aprobada por decreto ley $22231^{14}$, del 11 de julio de 1978. Para que no cupiera la menor duda sobre la adhesión a estos dos últimos textos, la Asamblea Constituyente, en la decimosexta disposición general

8 Mezger, Edmundo. Criminología. Madrid: Revista de Derecho Privado, 1942, pp. 3, 244 y 245.

9 Ver: http://www.un.org/es/documents/udhr/

10 Ver: http://www.congreso.gob.pe/ntley/Imagenes/Leyes/13282.pdf

11 Ver: http://www2.ohchr.org/spanish/law/ccpr.htm

12 Ver: http://www.congreso.gob.pe/ntley/Imagenes/Leyes/22128.pdf

13 Ver: http://www.oas.org/Juridico/spanish/tratados/b-32.html

14 Ver: http://www.congreso.gob.pe/ntley/Imagenes/Leyes/22231.pdf

LA CONSTITU-

CIONALIZACIÓN

DEL DERECHO

PROCESAL Y SU

REPERCUSIÓN EN

LA REFORMA DE

LA NORMATIVIDAD

RITUAL (CPP) Y EL

SISTEMA DE

JUSTICIA PENAL

CONSTITUTIO-

NALIZATION OF

ARBITRATION AND

ITS IMPACT IN

STANDARD

LEGISLATION

REFORM, CPP

(CRIMINAL

PROCEDURE

CODE) AND IN

CRIMINAL JUSTICE

SYSTEM 
y transitoria de la Carta Política de $19799^{15}$, estipuló que aquellos se ratificaban constitucionalmente, así como el Protocolo Facultativo del Pacto Internacional de Derechos Civiles y Políticos de las Naciones Unidas y los artículos 45 y 62 de la Convención Americana sobre Derechos Humanos, referidos a la competencia de su Comisión y Corte. El artículo 105 de la ley fundamental normó que:

Los preceptos contenidos en los tratados relativos a derechos humanos tienen jerarquía constitucional. No pueden ser modificados sino por el procedimiento que rige para la reforma de la Constitución.

La huella de estos tratados reluce evidente, por lo menos en el aspecto normativo, debido a que todos ellos contienen previsiones de naturaleza procesal penal.

La Declaración Universal de Derechos Humanos reconoce entre estos el derecho de la persona a la libertad y a la seguridad, a un recurso efectivo ante los tribunales que la ampare contra actos que violen sus derechos fundamentales, a ser oída públicamente y con justicia por un tribunal independiente e imparcial para el examen de cualquier acusación penal que se le ateste, a la presunción de inocencia mientras no se pruebe su culpabilidad conforme a ley y en juicio público, con todas las garantías para su defensa, y a la favorabilidad punitiva o sancionadora; asimismo, proscribe la desigualdad y discriminación, las torturas, penas u otros tratos crueles, inhumanos o degradantes y las detenciones arbitrarias, las condenas por hechos no previstos en la ley como delitos y las injerencias arbitrarias en su vida privada y familiar, su domicilio o correspondencia (ver los artículos 1, 2.2, 3, 5, 7, 8, 9, 10, 11 y 12).

El Pacto Internacional de Derechos Civiles y Políticos, recogiendo y desarrollando la tradición forjada por la Declaración Universal, acuña varias previsiones de enorme interés, como la interdicción de la tortura y otros tratos semejantes (artículo 7), el derecho a la libertad y seguridad personales —antípoda de la detención arbitraria- o privación de libertad fuera de los casos previstos por la ley, así como los procedimientos establecidos por esta, el derecho a conocer las razones de la detención y la acusación formulada, a ser conducido ante un juez y a ser juzgado en tiempo razonable o ser excarcelado, $y$ al recurso ante un Tribunal para que decida sobre la legalidad de la prisión y ordene la libertad si aquella fuera ilegal. Asimismo, la consideración de que la prisión preventiva de los procesados no debe ser la regla sino una excepción, y el derecho a ser reparado en caso de haber sufrido detención ilegal (artículo 9). 
Contempla, además, el trato humano y digno a los privados de libertad, la separación entre procesados y condenados y la existencia de un régimen penitenciario orientado hacia la reforma y readaptación social de los internos (artículo 10). También prevé la igualdad procesal, el derecho a ser escuchado públicamente y con todas las garantías por un tribunal competente, independiente, imparcial y predeterminado por la ley, en la substanciación de cualquier acusación penal, a la presunción de inocencia mientras no se prueba la culpabilidad del imputado, a la información sobre la naturaleza y causas de la acusación, a ser juzgado sin dilaciones indebidas, a hallarse en el proceso, a defenderse materialmente y ser asistido por un defensor técnico de su elección o de oficio, gratuitamente, a interrogar y hacer interrogar a los testigos de cargo y hacer concurrir a los de descargo, a contar con un intérprete cuando fuera necesario, a no ser obligado a declarar contra sí mismo ni a confesarse culpable, a la impugnación de los fallos condenatorios, a la revisión de estos y a la indemnización por los errores judiciales que los solventaron y a la cosa juzgada (artículo 14), a la vigencia del principio de legalidad de los delitos y penas (artículo 15), y a no ser objeto de injerencias ilegales en la vida privada, familiar, su domicilio o correspondencia (artículo 17).

La Convención Americana de Derechos Humanos, de un modo más sistemático, insiste en que toda persona tiene derecho a que se respete su integridad, que nadie debe ser objeto de tortura, penas o tratos crueles, inhumanos o degradantes, que la persona privada de libertad debe ser tratada con el respeto a la dignidad inherente al ser humano, que los procesados deben estar separados de los condenados (artículo 5: «Derecho a la integridad personal»), Asimismo consagra que a toda persona le asiste el derecho a la libertad y seguridad, en consecuencia, nadie puede ser privado de su libertad física sino en las condiciones fijadas por las constituciones o las leyes que de estas deriven, que están proscritos los encarcelamientos arbitrarios, que los detenidos deben ser informados de la razones de su detención y notificados del cargo que pesa en su contra, que deben ser llevados sin demora ante un juez y que les alcanza el derecho de ser juzgados dentro de un plazo razonable o a ser puestos en libertad, que, además tienen derecho a recurrir ante un juez para que decida sobre la legalidad de la detención y ordene su libertad si el arresto fuera ilegal (artículo 7: «Derecho a la libertad personal»), que la persona tiene derecho a ser oída, con las debidas garantías y dentro de un plazo razonable, por un juez competente, independiente e imparcial, predeterminado por ley, en la sustanciación de cualquier acusación contra ella, a la presunción de inocencia mientras no se determine su culpabilidad, a un proceso regido por la igualdad y ciertas garantías mínimas, como el derecho de ser asistido gratuitamente cuando corresponda,

LA CONSTITU-

CIONALIZACIÓN

DEL DERECHO

PROCESAL Y SU

REPERCUSIÓN EN

LA REFORMA DE

LA NORMATIVIDAD

RITUAL (CPP) Y EL

SISTEMA DE

JUSTICIA PENAL

CONSTITUTIO-

NALIZATION OF

ARBITRATION AND

ITS IMPACT IN

STANDARD

LEGISLATION

REFORM, CPP

(CRIMINAL

PROCEDURE

CODE) AND IN

CRIMINAL JUSTICE

SYSTEM 
por traductor o intérprete, la comunicación de la acusación planteada, de la concesión del tiempo y medios adecuados para la preparación de su defensa, el derecho de defensa material y técnica de elección o en su defecto de defensa de oficio, derecho a interrogar a los testigos presentes y de obtener la comparecencia de los testigos y peritos que puedan elucidar los hechos, a no ser obligado a declarar contra sí mismo ni a declararse culpable, a que la confesión solo sea válida si es hecha sin coacción, al recurso o impugnación, al ne bis in ídem en caso de sentencia absolutoria, a la publicidad del proceso penal (artículo 8: «Garantías judiciales»), al principio de legalidad de los delitos y las penas, a la retroactividad penal benigna (artículo 9: «Principio de legalidad y de retroactividad»), a la indemnización en caso de condena firme por error judicial (artículo 10: «Derecho de indemnización»), y a no ser objeto de injerencias abusivas en su vida privada o familiar, domicilio o correspondencia (artículo 11: «Protección de la honra y la dignidad»).

Efectuada la reseña de los tratados internacionales sobre derechos humanos y destacada su profunda huella en la elaboración de la Constitución de 1979, no disuena se afirme que recién luego de esa Carta se abrieran las posibilidades de construir un proceso penal auténticamente democrático, ajeno a las estipulaciones del caduco Código de Procedimientos Penales (C. de PP.) ${ }^{16}$, promulgado en 1939, vigente aún hoy —luego de mil parches — a partir de 1940.

El C. de PP trajo un modelo mixto, con predominio de notas inquisitivas, como la sobredimensionada etapa de instrucción en perjuicio de un debilitado juzgamiento. Este código, incapaz de comprender que el proceso penal no es una suma de procedimientos o secuencias, reprodujo las orientaciones y estilos de trabajo propios de la escrituración, haciendo del expediente su paradigma, corrosivo de la publicidad y oralidad.

Hay que apuntar que los defectos del C. de PP. fueron propios de su época, que se elaboró cuando en la escena mundial las políticas totalitarias de Hitler, Mussolini e Hirohito tenían gran aceptación y partidarios, que la humanidad tuvo que aprender trágicamente, durante la Segunda Guerra Mundial, la importancia de preservar la democracia y el Estado de derecho y que solo luego de esa prueba de fuego fue posible emprender el camino de la globalización de los derechos humanos y su consecuencia, la constitucionalización del proceso penal.

El fenómeno de globalización de los derechos humanos, iniciado hace más de medio siglo, ha conocido de avances y retrocesos, pero en términos generales puede decirse que constituye, aún hoy, la tendencia con la que simpatizan miles de millones de personas que buscan se respete

16 Ver: http://spij.minjus.gob.pe/CLP/contenidos.dll?f=templates\&fn=default-codprocpenales. htm\&vid=Ciclope:CLPdemo 
su dignidad y libertad. Muestra de esta tendencia es el establecimiento de la Corte Penal Internacional, según decisión aprobatoria de su estatuto, el 17 de julio de 1998, por la Conferencia Diplomática de Plenipotenciarios de las Naciones Unidades, en Roma, heredera de los tribunales de Nuremberg (1945), Tokio (1946), Rwanda (1994) y ex Yugoslavia (1993) ${ }^{17}$. La trascendencia de un colegiado universal para perseguir y castigar crímenes muy graves —entre ellos, los de lesa humanidad - alcanza tal dimensión que el CPP destina toda la Sección VII de su Libro Séptimo («La cooperación judicial internacional») ${ }^{18}$, a la colaboración con la Corte Penal Internacional (artículos 554-566), vigente desde el 1 de febrero de 2006, en razón de la Primera Disposición Final, numeral 4, modificada por las leyes 28460 (11 de enero de 2005) y 28671 (31 de enero de 2006) ${ }^{19}$.

No obstante el preclaro fenómeno de mundialización de los derechos humanos y constitucionalización del proceso penal, debe reconocerse que en el Perú la aplicación práctica de sus derivaciones normativas es retrasada y deficiente. Lo primero, porque transcurridos, desde 1979, veintisiete años, la justicia penal sigue atenazada por el modelo mixto del 40 y su acompañante más nocivo el procedimiento sumario, sin que finalmente entre en total vigor el modelo acusatorio; y, lo segundo, porque hay un estado de incertidumbre o promiscuidad normativa procesal penal, servida por la concurrencia de normas de orientación antagónica e incompatibles como son el C. de PP., las disposiciones procesales especiales, por ejemplo las leyes $28122^{20}$, que regula la conclusión anticipada de la instrucción en procesos por ciertos hechos punibles, y $27934^{21}$, que pauta la intervención de la policía y el Ministerio Público durante la investigación preliminar del delito; 22 artículos vigentes del CPP de 1991 como el 2 (principio de oportunidad y acuerdos reparatorios), 135 a 138 (mandato de detención y demás implicancias), 143 a 145 (comparecencia y otras derivaciones), 182 a 188 (libertad provisional) y 239 a 245 (diligencias especiales), y también algunos dispositivos del CPP: artículos 39 a 41 sobre transferencia de competencia, 210.4 y 213 , referidos al registro de personas y examen corporal para prueba de alcoholemia, 259 y 260 , en cuanto a la detención

17 Ver la resolución legislativa 27517, del 16 de septiembre de 2001, que aprueba el Estatuto de Roma de la Corte Penal Internacional, y el decreto supremo 079-2001-RE, del 9 de octubre de 2001, que lo ratifica.

http://www.congreso.gob.pe/ntley/lmagenes/Leyes/27517.pdf

18 Ver el decreto legislativo 983 , que modifica el artículo 523, referido al arresto provisorio o pre-extradición, y la ley 29305, que modifica los artículos 542 -alusivo a las condiciones para el traslado y el cumplimiento de condenas- y 544 -relativo al trámite cuando el Perú solicita el traslado del extranjero.

$19 \mathrm{http}: / /$ www.congreso.gob.pe/ntley/Imagenes/DecretosLegislativos/00983.pdf

http://www.congreso.gob.pe/ntley/lmagenes/Leyes/29305.pdf

Ver: http://www.congreso.gob.pe/ntley/Imagenes/Leyes/28460.pdf

http://www.congreso.gob.pe/ntley/lmagenes/Leyes/28671.pdf

20 Ver: http://www.congreso.gob.pe/ntley//magenes/Leyes/28122.pdf

21 Ver: http://www.congreso.gob.pe/ntley/Imagenes/Leyes/27934.pdf

LA CONSTITU-

CIONALIZACIÓN

DEL DERECHO

PROCESAL Y SU

REPERCUSIÓN EN

LA REFORMA DE

LA NORMATIVIDAD

RITUAL (CPP) Y EL

SISTEMA DE

JUSTICIA PENAL

CONSTITUTIO-

NALIZATION OF

ARBITRATION AND

ITS IMPACT IN

STANDARD

LEGISLATION

REFORM, CPP

(CRIMINAL

PROCEDURE

CODE) AND IN

CRIMINAL JUSTICE

SYSTEM 
policial en delito flagrante y el arresto ciudadano, 341, sobre el agente encubierto, 468 a 471 acerca del proceso especial de terminación anticipada, y el Libro Séptimo (artículos 508 a 566), que se ocupa de la cooperación judicial internacional, y sus disposiciones modificatorias.

Las amenazas contra la tendencia pro derechos humanos y el proceso penal democrático tampoco están ausentes, no son pocas y pueden detectarse en lo que se denomina «derecho penal del enemigo», descrita, al comentar críticamente las tesis de sus propulsores, por el profesor español Luis Gracia Martín:

Diferentes de los ciudadanos que han cometido un hecho delictivo son los enemigos. Estos son individuos que en su actitud [...], vida económica o mediante su incorporación a una organización, se han apartado del derecho $[\ldots]$ de un modo duradero [...) y que por ello, no garantizan la mínima seguridad cognitiva de un comportamiento personal y demuestran este déficit por medio de su comportamiento [...] Las actividades [...] de tales individuos no tienen lugar en el ámbito de relaciones sociales reconocidas como legítimas, sino [...] expresión de la vinculación de tales individuos a una organización estructurada que opera al margen del derecho [...] dedicada a actividades inequívocamente «delictivas» $[\ldots]$.

Las actividades de tales individuos se concretan generalmente en la comisión de hechos delictivos contra bienes jurídicos protegidos por el derecho penal $[\ldots]$, pero no son estos hechos los que constituyen la base $[\ldots]$ del derecho penal del enemigo, pues [...] los mismos en nada difieren de los realizados incidentalmente por los ciudadanos vinculados a y por el derecho. Los datos $[\ldots]$ que sirven de base a las regulaciones específicas del derecho penal del enemigo son la habitualidad y la profesionalidad de sus actividades [...] su pertenencia a organizaciones enfrentadas al derecho y el ejercicio de su actividad al servicio de tales organizaciones $[\ldots]$.

Los enemigos son individuos que se caracterizan $[\ldots]$ porque rechazan por principio la legitimidad del ordenamiento jurídico y persiguen la destrucción de ese orden [...] a consecuencia de ello, por su especial peligrosidad para el orden jurídico [y porque] no ofrecen garantías de la mínima seguridad cognitiva de un comportamiento personal, su (conducta) ya no es calculable conforme a las expectativas normativas vigentes en la sociedad [...].

Este llamado derecho penal del enemigo sería uno que se apartaría de los fines ordinarios del derecho penal [...] de la prevención [...] Se trataría más bien de una legislación de lucha o de guerra contra el enemigo cuyo único fin sería su exclusión e inocuización ${ }^{22}$.

22 Gracia MARTín, Luis. «Consideraciones sobre el actualmente denominado "derecho penal del enemigo"». Revista Peruana de Ciencias Penales, 16 (2005), pp. 376-379. Lima. 
Esta larga cita ha sido necesaria para denotar que en la actualidad en el ámbito penal y procesal penal existen voces muy insistentes que reivindican la urgencia de efectivizar a cualquier precio la represión punitiva, aun cuando ello signifique relajar y hasta desaparecer las garantías del debido proceso, como ocurre cuando se encierra indefinidamente a centenares de personas por simples sospechas o sin cargos y sin derecho a que un juez independiente e imparcial decida su situación, todo bajo el argumento que solo así es posible ganar la cruzada o «guerra» contra la criminalidad organizada, promovida por «enemigos» que han perdido la condición de personas y ciudadanos.

Algo de esto, la reducción o supresión de los derechos fundamentales del justiciable y la colocación de obstáculos para acceder a la protección de organismos supranacionales encargados de salvaguardar, entre otros, el proceso justo y legal, fue experimentado por el Perú con motivo de la resolución legislativa $27152^{23}$, del 8 de julio de 1999 , que por razones coyunturales y subalternas aprobó el retiro de la competencia contenciosa de la Corte Interamericana de Derechos Humanos, determinación que fuera respondida mediante comunicado de este organismo, el 27 de septiembre del mismo año, en el sentido que es «inadmisible la pretensión del Estado peruano de retira[r] con efectos inmediatos la [declaración de reconocimiento de la] competencia obligatoria de la Corte», como quedara establecido en sus sentencias sobre competencia, emitidas en los casos «Ivcher»y «Tribunal Constitucional» ${ }^{24}$, de fecha 24 de ese mes y año.

Dado este panorama, lo correcto es resguardar la orientación, el modelo y las vigas maestras que en materia procesal penal contienen los tratados internacionales y la Constitución de 1979. Se menciona específicamente esta Carta Política y no la hoy vigente, pese a que su Cuarta Disposición Final y Transitoria establece que las normas referidas a los derechos y libertades que la Constitución reconoce se interpretan de conformidad con la Declaración Universal de Derechos Humanos y con los tratados y acuerdos internacionales sobre las mismas materias ratificados por el Perú, por las sólidas objeciones que se hacen a la nacida en 1993, luego del pronunciamiento cívico-castrense de 5 de abril de $1992^{25}$, y por la actividad del llamado Congreso Constituyente

23 Ver: http://www.aprodeh.org.pe/public/ciddhh/c_july50.htm

24 Ver: http://www.corteidh.or.cr/docs/casos/articulos/Seriec_54_esp.pdf http://www.corteidh.or.cr/docs/casos/articulos/Seriec_55_esp.pdf

25 Decreto ley 25418, Ley de Bases del Gobierno de Emergencia y Reconstrucción Nacional, en especial los artículos «4.- Disuélvase el Congreso de la República hasta la aprobación de una nueva estructura del Poder Legislativo [...] 5.- El presidente de la República, con el voto aprobatorio del Consejo de Ministerios [...] ejercerá las funciones que corresponden al Poder Legislativo [y] 8.Déjese en suspenso los artículos de la Constitución política y las normas legales que se opongan al presente decreto ley".

Ver: http://www.congreso.gob.pe/ntley/Imagenes/Leyes/25418.pdf

LA CONSTITU-

CIONALIZACIÓN

DEL DERECHO

PROCESAL Y SU

REPERCUSIÓN EN

LA REFORMA DE

LA NORMATIVIDAD

RITUAL (CPP) Y EL

SISTEMA DE

JUSTICIA PENAL

CONSTITUTIO-

NALIZATION OF

ARBITRATION AND

ITS IMPACT IN

STANDARD

LEGISLATION

REFORM, CPP

(CRIMINAL

PROCEDURE

CODE) AND IN

CRIMINAL JUSTICE

SYSTEM 
Democrático $^{26}$, sin dejar de advertir que en la materia que interesa, las grandes pautas de 1979 se mantuvieron - aunque fuera solo en la letra - en 1993. Sobre la vigente ley fundamental, su azarosa vida y rigor, son muy instructivas las sentencias del Tribunal Constitucional, emitidas en las acciones de inconstitucionalidad planteadas por el Colegio de Abogados del Cusco contra la ley $27600^{27}$ (retiro de firma de expresidente y reforma de la Constitución) y el doctor Borea Odría y otros contra el «documento promulgado el 29 de diciembre de 1993 con el título de Constitución Política del Perú de 1993», expedientes 00142002-AI/TC y 0014-2003-AI/TC, respectivamente ${ }^{28}$.

Sin asegurar que en adelante no se presentarán más situaciones adversas al reconocimiento de los derechos fundamentales, incluidas las garantías procesales penales, es bueno recordar con satisfacción que la resolución legislativa $27401^{29}$, del 18 de enero de 2001, restableció a plenitud para el Estado peruano la competencia contenciosa de la Corte Interamericana de Derechos Humanos, y que la ley 27775, del 5 de julio de 2002, reguló el procedimiento de ejecución de sentencias de los tribunales supranacionales.

\section{I.4. Garantías procesales o escudos protectores del justiciable. La postura del profesor Alberto Binder, propulsor de la reforma en América Latina}

El proceso penal ideal es aquel que encuentra punto de equilibrio entre el eficaz servicio a la seguridad y los reclamos de paz y sosiego colectivos y de las víctimas ante el delito, y el respeto a los derechos fundamentales del imputado.

Todo proceso, incluido el penal, alcanzará la condición de mecanismo de resolución de conflictos con relevancia jurídica, en la medida que proporcione el escenario para un adecuado debate entre los titulares de las pretensiones enfrentadas y para que el tercero imparcial, que valora la actividad probatoria de ellos, emita un fallo justo.

Desde esta perspectiva, la maquinaria procesal penal no puede construirse omitiendo reconocer las potestades, los derechos y las obligaciones de los sujetos procesales que participan en ella, porque tal actitud conspiraría contra los fines mismos del proceso, que son elucidar la verdad concreta

\footnotetext{
26 Decreto ley 25557. Convoca a elecciones para representantes al Congreso Constituyente Democrático a realizarse el 22 de noviembre de 1992.

Ver: http://www.congreso.gob.pe/ntley/lmagenes/Leyes/25557.pdf

27 Ver: http://www.congreso.gob.pe/ntley/Imagenes/Leyes/27600.pdf

28 Ver: http://www.tc.gob.pe/jurisprudencia/2003/00014-2002-Al.html

http://www.tc.gob.pe/jurisprudencia/2003/00014-2003-Al.html

29 Ver: http://www.congreso.gob.pe/ntley/lmagenes/Leyes/27401.pdf
} 
y determinar y realizar — o no_- la pretensión punitiva estatal mediante una condena o a través de una absolución.

En materia procesal penal, debido a que en ella se ventilan asuntos complejos como la potestad de perseguir y sancionar delitos y las consiguientes injerencias y restricciones del derecho fundamental a la libertad, no es correcto sobredimensionar los aparatos de persecución e investigación del Estado, como el Ministerio Público y la Policía Nacional, y de esta manera, debilitar los escudos protectores del justiciable contra la arbitrariedad. Toca, en cambio, confirmar la imparcialidad judicial que los restablezca si son avasallados.

Aunque la academia clasifica de diversa manera las garantías procesales y sostiene, por ejemplo, que son genéricas si guían todo el desenvolvimiento de la actividad procesal, o específicas si aluden aspectos concretos del procedimiento, de la estructura o actuación de los órganos penales ${ }^{30}$, o les asigna el nombre de principios relacionados con la organización del sistema de enjuiciamiento o con la iniciación del procedimiento, la prueba y la forma de aquel ${ }^{31}$, o por último las entiende orgánicas cuando atañen a la formación del juez, y estrictamente procesales si tienen que ver con la formación del juicio ${ }^{32}$, lo cierto es que todas pueden y deben ser reconducidas hacia el gran objetivo de proteger al incriminado, quien solo podrá ser vencido legítimamente si en el proceso no se ha desconocido su dignidad y los derechos que de ella emanan. Ha de quedar claro que las garantías procesales no se estipulan para satisfacer los requerimientos oficiales del Estado o de sus aparatos fiscales, policiales y judiciales, sino para que los destinatarios del servicio de justicia penal, la comunidad, los agraviados y procesados sean resguardados y satisfechos.

Todo proceso — también el penal- dirigido a resolver conflictos con relevancia jurídica incorpora inexcusables garantías que toma directamente de la Ley Suprema, como son la preeminencia indiscutible de las normas constitucionales, la potestad jurisdiccional popular ejercida por el Poder Judicial, independiente e imparcial, la irretroactividad de la ley, el debido proceso y la tutela jurisdiccional (artículos 51, 138 y 139 Constitución).

Sin desoír tan señaladas garantías, cuando se enfoca la mirada en el proceso penal destacan dos más: el juicio previo y la presunción de inocencia, seguidas de varias otras. Para tenerlas en cuenta

30 San Martín Castro, César. Derecho procesal penal, Volumen I. Cuestiones generales del derecho procesal Penal. Jurisdicción y competencia penal. Las partes procesales. Acción y objeto procesal. Estructura del proceso penal. Segunda edición actualizada y aumentada. Lima: Grijley, 2003, pp. 81 y 82.

31 LóPez BARJA DE QUiRogA, Jacobo. Tratado de derecho procesal penal. Cizur Menor, Navarra: Aranzadi Thomson, 2004, pp. 319-353.

32 FerRAJOLI, Luigi. Derecho y razón. Teoría del garantismo penal. Madrid: Trotta, 1998, p. 539.

LA CONSTITU-

CIONALIZACIÓN

DEL DERECHO

PROCESAL Y SU

REPERCUSIÓN EN

LA REFORMA DE

LA NORMATIVIDAD

RITUAL (CPP) Y EL

SISTEMA DE

JUSTICIA PENAL

CONSTITUTIO-

NALIZATION OF

ARBITRATION AND

ITS IMPACT IN

STANDARD

LEGISLATION

REFORM, CPP

(CRIMINAL

PROCEDURE

CODE) AND IN

CRIMINAL JUSTICE

SYSTEM 
permanentemente y no condenarlas a letra muerta, archivadas en el desván de los operadores, se ha sugerido, como enseña Binder, agruparlas en tres niveles por estricta razón práctica: (i) que recoge todas las garantías destinadas a impedir la manipulación del proceso penal; (ii) que integra las que limitan la potestad del Estado de buscar información probatoria, y (iii) que asocia las orientadas a limitar el empleo de la fuerza (coerción) en el proceso ${ }^{33}$

\section{I.4.1. Prevalencia de la norma constitucional}

Si la Constitución es entendida como suprema manifestación normativa del consenso y acuerdo fundacional y político de los ciudadanos asociados, entonces debe reconocerse que todas las normas ordinarias que regulan las actividades de aquellos, incluida el área de resolución de conflictos jurídico-penales, tienen que exhibir compatibilidad constitucional so pena de expulsión del ordenamiento jurídico a través del control concentrado del Tribunal Constitucional o declaradas inaplicables al caso, mediante control difuso judicial (artículos 51, 138. Segundo párrafo, 200.4, 201, 202.1 y 204 Constitución).

Esta necesaria coherencia normativa no es un guiño sistemático sino la forma más explícita de sopesar e interpretar una ley o disposición en conflicto con los derechos fundamentales constitucionales, por ejemplo, el de defensa. Tal sería el caso del artículo 73 del C. de PP., que al ocuparse de la reserva de la instrucción o investigación no hace clara diferencia entre reserva, esto es, conocimiento habilitado solo para los que tienen calidad de sujetos procesales, y secreto del sumario o imposibilidad de conocimiento por las partes de ciertas actuaciones, lo cual ha permitido que ganen carta de ciudadanía ciertas posiciones, como las que dicen que el inculpado o su defensor no pueden conocer el expediente sino hasta luego de la rendida instructiva ${ }^{34}$, o que el secreto del sumario se impone a todo lo actuado, incluida la denuncia y el mismísimo auto de apertura de instrucción, verdadero despropósito aflictivo del derecho a conocer la imputación y sus fundamentos, imprescindible para organizar la resistencia y cuestionamiento de la persecución penal.

\section{I.4.2. Potestad jurisdiccional popular y Poder Judicial}

Aunque resulta formalmente paradójico decirlo, la justicia no les pertenece a los jueces que la arbitran, sino al pueblo, fuente originaria y colectivo social interesado en que los conflictos generados por el delito no acarreen una respuesta más violencia, propia de la acción directa o justicia por propia mano, sino una solución o redefinición del conflicto que restablezca la paz y tranquilidad comunes y los derechos de la víctima. 
Los jueces y demás actores de la justicia penal no son válidos del mandón o gobernante de turno, como se estilaba admitir durante el Virreinato y los difíciles primeros años de nuestra convulsionada República, sino servidores del pueblo cuya fuerza viene de él para controlar los excesos de los demás poderes públicos y preferir las libertades del ciudadano (artículos 138. Primer párrafo, 1 y 2 Constitución). Los jueces tendrían que ser el último valladar de defensa de la democracia frente a la arbitrariedad oficial y también de los juicios paralelos o mediáticos que tienen en la prensa un grupo de presión autoproclamado perseguidor, decisor y hasta verdugo.

La potestad popular en el proceso penal no puede enervarse, pues la justicia no solo interesa al pueblo sino que debe caer bajo su estricto control. A la sociedad le es consustancial conocer qué hacen sus jueces y cómo actúan, cuán eficaces y justos son. La mejor forma de conseguir que este mandato constitucional se concrete es generalizando y preservando la publicidad de los juicios penales; no hay nada más antidemocrático que sofocar las causas en un ambiente de sombras favorecido por el secreto y la escritura, propias del modelo inquisitivo. Sin juicio público, sostenido por su fundamental herramienta, la oralidad, no existe auténtico proceso, sino un prescindible bulto de trámites burocráticos.

A propósito de lo dicho, se ha lanzado la pregunta de si ha llegado el momento de instituir el juicio por jurados populares, como tímida y teóricamente se intentó con el Código de Procedimientos en Materia Criminal de $1920^{35}$. Al redactarse los CPP de 1991 y 2004 se ha guardado silencio al respecto, por lo que habrá de admitirse que las condiciones no están dadas para la estipulación de una institución tan interesante y compleja como es el jurado, de ahí que sea decisivo persistir en la publicidad procesal si no se quiere seguir ahondando el distanciamiento de la justicia del pueblo y la deslegitimación del servicio.

\section{I.4.3. Irretroactividad de la ley}

Esta garantía confirma la seguridad jurídica a la que todos tienen derecho, pues si la regulación de una determinada situación pudiese ser afectada en su ámbito temporal por los cambios normativos ulteriores sería imposible alcanzar estabilidad y reinaría un estado de incertidumbre y completa provisionalidad.

35 CALLE, Juan José. Código de procedimientos en materia criminal, promulgado por el Poder Ejecutivo el 2 de enero de 1920, anotado y concordado. Lima: Librería e Imprenta Gil, 1920, pp. 18 y 91-92. Artículos 22 y 183 :

"Los crímenes, ó sean todas las infracciones penadas con la muerte ó penitenciaría, el infanticidio y además los delitos contra la seguridad exterior del Estado y los delitos de rebelión, sedición, motín y asonada, serán sometidos al jurado [...]».

«El juicio será oral y público, lo mismo ante los tribunales correccionales que juzgarán los delitos, que ante el jurado que juzgará los crímenes».

LA CONSTITU-

CIONALIZACIÓN

DEL DERECHO

PROCESAL Y SU

REPERCUSIÓN EN

LA REFORMA DE

LA NORMATIVIDAD

RITUAL (CPP) Y EL

SISTEMA DE

JUSTICIA PENAL

CONSTITUTIO-

NALIZATION OF

ARBITRATION AND

ITS IMPACT IN

STANDARD

LEGISLATION

REFORM, CPP

(CRIMINAL

PROCEDURE

CODE) AND IN

CRIMINAL JUSTICE

SYSTEM 
Esa inestabilidad, nociva para cualquier relación jurídica, es más grave cuando de asuntos penales se trata, porque las conductas criminalizadas y sus penas abstractas no pueden ser reguladas sino mediante ley previa. A esto se llama irretroactividad de la ley penal material, instituto compatible con la retroactividad y ultractividad benignas de la norma punitiva (artículo 103 Constitución). Lo que interesa, sin embargo, es saber si también la irretroactividad opera cuando se predica de normas procesales penales.

En este asunto, el principio admitido es que todo acto procesal se rige por la ley procesal vigente al momento de su realización, a diferencia del criterio que regula la vigencia temporal de la ley penal material, que indica que la aplicable es la vigente al momento de la comisión del delito. Se arguye que la diferencia radica en que el objeto tratado por una y otra normas es distinto, olvidándose aquellas situaciones en que ciertos cambios procesales no se circunscriben a lo ritual o procedimental, sino que afligen derechos fundamentales del justiciable como la libertad y su restricción coercitiva. En estos supuestos, ida lo mismo aplicar la nueva ley procesal más restrictiva de la libertad del procesado o seguir aplicando ultractivamente la anterior, menos perjudicial? El Tribunal Constitucional en este tema ha tomado, en momentos diferentes, dos posiciones. La primera, entre otras causas, en el expediente 2273 2002-HC/TC, Lima, sentencia del 9 de julio de 2002, caso Mejía ${ }^{36}$, al indicar:

4. Este Tribunal Constitucional debe señalar que en el presente caso el plazo máximo de detención no es de dieciocho meses, conforme lo prevé la ley $27553^{37}$, de fecha 13 de noviembre de 2001, pues de ser esto así, supondría la aplicación retroactiva de una norma más gravosa y aflictiva al derecho fundamental a la libertad personal, por cuanto incrementa los plazos de duración de la detención, que estableciera el decreto ley $25824^{38}$, esta última vigente cuando se le instauró proceso penal a la actora y por ello aplicable en virtud del principio de ultractividad benigna en la aplicación temporal de la ley penal; lo cual es conforme con el artículo 103 de la Constitución Política del Estado.

La segunda posición, entre varias sentencias, reluce en la emitida el 27 de agosto de 2003, en el expediente 1300-2002-HC/TC, caso Eyzaguirre ${ }^{39}$, al sostener:

5. La Ley 27553 entró en vigencia el 14 de noviembre de 2001, y modificó el artículo 137 del [CPP] respecto del plazo de detención [...], el cual ahora cambió a 18 meses

36 Ver: http://www.tc.gob.pe/jurisprudencia/2003/02273-2002-HC.html 37 Ver: http://www.congreso.gob.pe/ntley/lmagenes/Leyes/27553.pdf 38 Ver: http://www.congreso.gob.pe/ntley/Imagenes/Leyes/25824.pdf 39 Ver: http://www.tc.gob.pe/jurisprudencia/2003/01300-2002-HC.html 
6. Es necesario [...] determinar en qué casos opera el nuevo plazo de detención, y, en qué casos, el antiguo [...].

7. En el derecho procesal, el acto procesal está regulado por la norma vigente al momento en que este se realiza.

8. Así, el artículo 103 de la Constitución dispone que «ninguna ley tiene fuerza ni efecto retroactivos, salvo en materia penal cuando favorece al reo». Esta excepción es aplicable a las normas del derecho penal material $[\ldots]$.

9. En el derecho procesal [...] rige también la aplicación inmediata de normas en tanto el proceso se desarrolla de acuerdo a las normas vigentes durante el mismo [...].

10. El artículo 139, inciso 119 de la Constitución establece que en caso de duda o conflicto de leyes penales, se debe aplicar la norma más favorable. Esta regla solo es aplicable en el derecho penal sustantivo [...].

11. La ley puede también establecer precisiones específicas acerca de la aplicación temporal de las normas, las [...] que serán válidas siempre y cuando no contravengan la prohibición constitucional de la retroactividad normativa. Por ejemplo, el artículo IX del Título Preliminar del (CPP), establece que son aplicables las normas vigentes al inicio del proceso «inclusive para lo que resta del proceso [...], siempre que se trate de disposiciones más favorables». No obstante, este artículo no ha entrado aún en vigencia, por lo que no resulta aplicable [...].

14. La ley 27533, que modifica el artículo 137 del (CPP), tiene en su disposición transitoria una norma que regula su aplicación en el tiempo, la cual establece que será aplicada a los procesos en trámite [...] Ello significa que podrá regular casos en los que la detención ha sido ordenada cuando la antigua regulación del [referido artículo] del (CPP) estaba vigente $[\ldots]$.

16. Asimismo [...], en caso de que a la entrada en vigencia de la ley 27553 el plazo de detención aún no haya vencido, será de aplicación el nuevo plazo de detención.

Sobre la vigencia temporal de la ley procesal penal, la Comisión Interamericana de Derechos Humanos emitió un dictamen adverso a los efectos retroactivos de ella, con ocasión del Informe 83/00, caso 11688 Perú (García Pérez), en el cual sostuvo, a propósito de la aplicación de la ley $26641^{40}$, que suspende la prescripción de la acción penal por razón de contumacia:

46. - A su vez, el principio de retroactividad de la ley penal permisiva o favorable en materia criminal, y [...] la garantía de la no retroactividad

LA CONSTITU-

CIONALIZACIÓN

DEL DERECHO

PROCESAL Y SU

REPERCUSIÓN EN

LA REFORMA DE

LA NORMATIVIDAD

RITUAL (CPP) Y EL

SISTEMA DE

JUSTICIA PENAL

CONSTITUTIO-

NALIZATION OF

ARBITRATION AND

ITS IMPACT IN

STANDARD

LEGISLATION

REFORM, CPP

(CRIMINAL

PROCEDURE

CODE) AND IN

CRIMINAL JUSTICE

SYSTEM 
de la ley restrictiva o desfavorable, abarca por igual tanto los preceptos sustantivos como los adjetivos o de procedimiento que afecten cuestiones de derecho sustantivo. Esta extensión de la denomina garantía contra leyes ex post facto a materia procesal penal [...] ha sido producto de la evolución del derecho penal y procesal penal [...].

47. [...] Doctrinantes como Jiménez de Asúa sostienen que «si las nuevas formas de enjuiciamiento contienen disposiciones que influirán en la penalidad en la defensa del imputado, no podrá dárseles efecto retroactivo, porque no es posible someter al acusado a condiciones más graves que las previstas por la ley vigente en el momento en el que el delito se perpetró» ${ }^{41}$.

\section{I.4.4. Debido proceso y tutela jurisdiccional}

El debido proceso o derecho a un proceso justo y legal, esto es, transparente, ajustado a ley y con garantías, es un escudo protector mayor que acoge y confirma bajo su sombra los presupuestos esenciales de configuración del mecanismo procesal democrático, de modo que a partir de él también quedan incluidos derechos que, aunque explícitamente no se reseñan en la Constitución o la ley procesal ordinaria, dimanan, como los explícitos, del espíritu civilizado de ella.

Aunque la trascendencia de esta garantía reside en los asertos de que no hay responsabilidad o declaración de culpabilidad sin juicio, acusación y defensa ${ }^{42}$, lo distintivo de ella reposa en que la actuación jurisdiccional en sus múltiples manifestaciones no puede ni debe ser arbitraria o irrazonable; proceder así niega el estándar de justicia democrática y deslegitima las decisiones de los órganos judiciales.

Con razón se afirma que el imperativo del debido proceso se despliega a partir de la $\mathrm{V}$ enmienda constitucional de los Estados Unidos de América, de ahí el interés que tiene reparar en que su fórmula vincula las más graves injerencias estatales sobre los derechos de las personas, como la vida, libertad o propiedad, a la existencia con el desarrollo de un debido proceso judicial, exento de abuso o arbitrariedad $^{43}$; es decir, afirma que las garantías procesales no son ritos o formalismo sino concreción operativa de los escudos protectores del justiciable.

41 Valle RieStRA, Javier. «Irretroactividad nociva de normas procesales, penales y penitenciarias y la claudicación del Tribunal Constitucional». Actualidad Jurídica, publicación mensual de Gaceta Jurídica, 2004, Tomo 123, febrero, Lima, p. 11.

42 FERRAJOLI, Luigi. Ob. cit., p 538.

43 V Enmienda: «Ninguna persona será detenida para que responda por un delito capital, o infamante por algún concepto, sin un auto de denuncia o acusación formulado por un Gran Jurado [...] tampoco podrá someterse a una persona dos veces, por el mismo delito, al peligro de perder la vida o sufrir daños corporales; tampoco podrá obligársele a testificar contra sí mismo en una causa penal, ni se le privará de la vida, la libertad o la propiedad sin el debido proceso judicial [...]. 
La vitalidad expansiva del debido proceso bien puede ejemplificarse con el acogimiento que hace del derecho, no explícito en la Constitución vigente, a ser juzgado sin dilaciones indebidas, entendido como el que asiste a todo procesado a que su situación jurídica se resuelva en tiempo apropiado, sin ser regular que la causa se dilate indefinidamente por la lentitud y omisiones de los funcionarios a cargo o se restrinja hasta imposibilitar el ejercicio de la defensa. Muy instructiva resulta al respecto la sentencia de la Corte Interamericana de Derechos Humanos, del 29 de enero de 1997, expedida en el caso "Genie Lacayo» ${ }^{44}$, que en sus párrafos 74 y 77 estipula:

74. El artículo 8 de la Convención que se refiere a las garantías judiciales consagra los lineamientos del llamado «debido proceso legal» $\mathrm{O}$ «derecho de defensa procesal», que consisten en el derecho de toda persona a ser oída con las debidas garantías y dentro de un plazo razonable por un juez o tribunal competente, independiente e imparcial, establecido con anterioridad por la ley, en la sustanciación de cualquier acusación penal formulada en su contra o para la determinación de sus derechos de carácter civil, laboral, fiscal u otro cualquiera.

\section{[...]}

77. El artículo 8.1 de la Convención también se refiere al plazo razonable. Este no es un concepto de sencilla definición. Se pueden invocar para precisarlo los elementos que ha señalado la Corte Europea de Derechos Humanos en varios fallos en los cuales se analizó este concepto, pues este artículo de la Convención Americana es equivalente en lo esencial, al 6 del Convenio Europeo para la Protección de Derechos Humanos y de las Libertades Fundamentales. De acuerdo con la Corte Europea, se deben tomar en cuenta tres elementos para determinar la razonabilidad del plazo en el cual se desarrolla el proceso: a) la complejidad del asunto; b) la actividad procesal del interesado; y c) la conducta de las autoridades judiciales (ver entre otros, Eur. Court H.R., Motta judgment of 19 February 1991, Series A 195-A, párr. 30; Eur. Court H.R., Ruiz Mateos v. Spain judgment of 23 June 1993, Series A 262, párr. 30).

A diferencia del aviso colocado en las puertas del infierno: «Abandona toda esperanza», en el pórtico de las causas penales el principio del debido proceso advierte a los jueces que deben actuar con justicia y sujetarse a la Constitución, la ley y demás formalidades procesales garantizadoras; y al justiciable, que el enjuiciamiento no se hará al costo de suprimir

LA CONSTITU-

CIONALIZACIÓN

DEL DERECHO

PROCESAL Y SU

REPERCUSIÓN EN

LA REFORMA DE

LA NORMATIVIDAD

RITUAL (CPP) Y EL

SISTEMA DE

JUSTICIA PENAL

CONSTITUTIO-

NALIZATION OF

ARBITRATION AND

ITS IMPACT IN

STANDARD

LEGISLATION

REFORM, CPP

(CRIMINAL

PROCEDURE

CODE) AND IN

CRIMINAL JUSTICE

SYSTEM 
su dignidad o las condiciones indispensables para la concreción de sus derechos fundamentales.

El derecho a la tutela judicial, en palabras del profesor Picó y Junoy, que para efectos de definición resume la posición del Tribunal Constitucional español, tiene un contenido complejo que incluye: el derecho de acceso a los órganos jurisdiccionales o al proceso, a obtener de ellos una sentencia fundada en derecho congruente, a la efectividad o ejecución de las resoluciones judiciales, y el derecho al recurso legalmente previsto ${ }^{45}$.

El acceso a los órganos jurisdiccionales adquiere significado tanto desde la perspectiva de la sociedad, a quien importa la resolución de los conflictos suscitados por el delito, y del agraviado y sus legítimos reclamos de resarcimiento e indemnización, cuanto desde la óptica del incriminado, quien espera que las imputaciones que se le hacen sean filtradas por todos los controles procesales para evitar abusos o errores en la eventual determinación de su responsabilidad y sanción. El hecho de que el titular del ejercicio público de la acción penal sea el Ministerio Público no implica finalmente que los asuntos sometidos por este a conocimiento y decisión de los jueces salgan del ámbito social o se desvinculen de los intereses de las víctimas, menos que el imputado sea un sujeto procesal de segundo orden.

Ahora bien, esta garantía no afirma que las partes tengan derecho a que el órgano jurisdiccional les dé la razón o confirme sus pretensiones, sino a que este resuelva o falle el fondo del asunto conforme a derecho, sobre la base de una motivación sólida y congruente, y a que se ejecute lo decidido, lo que explica, por ejemplo, cuán frustrante es que la mayoría de reparaciones civiles establecidas por los jueces penales no se efectivicen, como demostración de impotencia institucional.

Queda expuesta así la inteligencia que existe entre el debido proceso y la tutela judicial, de lo que da cuenta el artículo 139.3 de la Constitución.

\section{I.4.5. Juicio previo y presunción de inocencia}

Además de las garantías examinadas, que el proceso penal comparte con los demás mecanismos de resolución de conflictos, interesa analizar las que lo definen y distinguen, siendo las más notorias el juicio previo y la presunción de inocencia, cuyas proyecciones iluminan el significado del resto de derechos del justiciable.

El juicio previo que estipula el artículo 139.10 de la Constitución, o principio de no ser penado sin proceso judicial, impone la existencia de un escenario procesal al que ingresa la pretensión punitiva del fiscal y la libertaria del acusado, para que en condiciones de publicidad, 
oralidad, igualdad de armas, contradicción e inmediación se practique, esencialmente por estas partes, la prueba de cargo o descargo, cuyo resultado será valorado, según las reglas de la lógica, la ciencia y la experiencia, por el órgano judicial imparcial, quien emitirá fallo motivado de absolución o condena. Esta es la concepción de juicio previo que no admite confusión con alguna tosca secuencia procesal, de modo que al hablarse de proceso penal común tendrá que distinguirse su etapa principal, decisiva, el juzgamiento, de las preparatorias o de saneamiento (investigación y etapa intermedia), pensadas y articuladas en función del primero.

En cuanto a la presunción de inocencia ha de indicarse que se trata de una garantía que alcanza la condición de derecho fundamental, conforme al artículo 2.24.e de la Ley Suprema, y que se explica en la medida en que un Estado democrático entiende su sociedad como colectivo de hombres libres, como tierra de libertad y no de sospecha, en la que está prohibido generalizar las incriminaciones o los operativos de persecución del delito si no existe causa probable, como proscrito, también, declarar responsabilidades delictuosas y sancionar si se carece de prueba de cargo suficiente o media duda.

Porque nadie es culpable hasta que debida y legalmente es declarado como tal, los procesados mantienen su calidad de inocentes y gozan de los derechos que les permitan resistir la persecución y, cuando así lo decidan, desvirtuarla, contando para el efecto de defensa material y técnica, de elección o pública, asignada por el Estado.

Como hace notar Faustino Cordón Moreno al resumir la jurisprudencia del Tribunal Constitucional español, la presunción de inocencia niega que el acusado llegue al juicio con una conducta incierta respecto de su culpabilidad que el juez haya de concretar en función de argumentos más abundantes o convincentes: aquel —dice- llega como inocente y solo puede salir culpable si su condición de inocente resulta plenamente desvirtuada por el juez a partir de las pruebas aportadas por la acusación. La presunción de inocencia — agrega - se mantiene incólume si de lo actuado se nota un vacío o insuficiencia probatoria en razón de ausencia de pruebas o que las realizadas han sido obtenidas ilícitamente o si el razonamiento del juez es manifiestamente absurdo o arbitrario; habrá de decaer, en cambio, cuando existan pruebas de cargo, directas o indiciarias, con suficiente peso inculpador ${ }^{46}$. 


\section{I.4.6. Garantías que evitan la manipulación del proceso}

Según ya se dijo, la referencia a las garantías procesales penales interesa en su dimensión práctica y operativa (Binder), y con mayor razón en países como el Perú, donde la democracia ha apurado momentos extremadamente difíciles, como son largos períodos de caos y desinstitucionalización, o estados de excepción impuestos como regla ${ }^{47}$.

Son esas eventualidades las que casi siempre han motivadointervenciones contra el Poder Judicial a través del fácil expediente de ceses masivos, recubiertos con el ropaje de «reformas», interesadas más en someter las decisiones de los órganos jurisdiccionales a intereses subalternos de gobiernos, partidos, clases o grupos — esto es, coyunturales — siendo una de sus primeras víctimas el proceso penal, transformado así de mecanismo de resolución de conflictos en arma arrojadiza de persecución, amenaza y hasta «cortina de humo».

Ante el permanente riesgo de manipulación del proceso penal se erigen las garantías orientadas a conjurarlo; en la Constitución destacan las siguientes:

a) La independencia, unidad y exclusividad de la función jurisdiccional, así como la licitud y legitimidad del nombramiento de los magistrados, lo que repele los avocamientos e interferencias procedentes de otros organismos o funcionarios en causas judiciales pendientes (artículo 139.2, 1, 19 y 17).

b) La jurisdicción y el procedimiento predeterminados, negadores de los órganos jurisdiccionales de excepción o las comisiones especiales (artículo 139.3).

c) La existencia de un órgano civil autónomo, el Ministerio Público, no castrense, ni policivo, encargado de la persecución del delito y de la dirección integral de la investigación de aquel, con respaldo operativo policial (artículos 158, 159 y 166).

d) El derecho de defensa material y técnica, de elección o pública, que implica, además, el de información inmediata y escrita de la causas o razones de la detención (artículo 139.14, 15 y 16).

47 Para sopesar el período republicano de anarquía y desconcierto y el imperio de los regímenes de excepción, con toda su carga de arbitrariedad penal, ver: BASADRE, Jorge. Historia de la República del Perú 1822-1933. Lima: Editorial Universitaria, 1983. tomos I, pp 249 y ss., y X, pp 229 y ss.; asimismo el contenido de dispositivos como la ley 24150 , de 7 de junio de 1985 , que crea los comandos político-militares, el decreto legislativo 749, del 12 de noviembre de 1991, que refuerza el predominio de estos sobre las demás autoridades en zonas declaradas en emergencia, ambos declarados en parte inconstitucionales mediante sentencia del Tribunal Constitucional, pronunciada en el expediente, promovido por la Defensoría del Pueblo, 017-2003-Al/TC, y publicada el 23 de agosto de 2004. Esta sentencia ha dado lugar a correctivos como la ley 28222, del 18 de mayo de 2004.

Ver: http://www.congreso.gob.pe/ntley/Imagenes/Leyes/24150.pdf http://www.congreso.gob.pe/ntley//magenes/DecretosLegislativos/00749.pdf http://www.tc.gob.pe/jurisprudencia/2004/00017-2003-Al.html http://www.congreso.gob.pe/ntley/lmagenes/Leyes/28222.pdf 
e) La publicidad en el proceso, amiga de la oralidad y de las técnicas de la litigación y contraria a la escrituración y el secreto, especialmente cuando se trata de asuntos referidos a la responsabilidad de funcionarios públicos, y delitos cometidos por medio de la prensa y contra los derechos fundamentales (artículo 139.4).

f) La aplicación de la ley más favorable al procesado en caso de duda o conflicto entre leyes penales y la inaplicabilidad por analogía de la ley penal y de las normas que restrinjan derechos (artículo 139.11 y 9).

g) La motivación de la resoluciones judiciales, con expresa indicación de los fundamentos de hecho y de derecho invocados (artículo 139.5).

h) El ne bis in idem tanto material (cosa juzgada y sobreseimientos) como procesal, o prohibición de doble sanción o procesamiento contra la misma persona y por el mismo delito (artículo 139.13).

i) La obligación del Poder Ejecutivo de prestar en los procesos judiciales la colaboración que le sea requerida.

j) El derecho al recurso o impugnación, denominado también garantía de instancia plural (artículo 139.6).

k) La improcedencia de las condenas en ausencia (artículo 139.12).

1) La indemnización por los errores judiciales y detenciones arbitrarias (artículo 139.7).

m) El análisis y crítica de la resoluciones y sentencias judiciales (artículo 139.20).

\section{I.4.7. Garantías que restringen la potestad estatal de búsqueda de información probatoria}

La coincidencia de la doctrina en el sentido que la vitalidad del proceso penal depende de la fortaleza de la actividad probatoria desarrollada en su seno, no confirma que los fines procesales validan el ejercicio de la prueba a cualquier costo, en la medida que ni siquiera los órganos oficiales de investigación están autorizados a recolectar información probatoria de modo irrestricto, sin respetar las fronteras constituidas por los derechos fundamentales de la persona.

La actuación probatoria, que comprende la ubicación, identificación y obtención de fuentes de prueba y la incorporación a proceso de los elementos acreditativos de los hechos, a través de los medios probatorios pertinentes, será inútil y perderá poder de convicción si carece de legitimidad, si se ha practicado con infracción de las reglas constitucionales de garantía.

LA CONSTITU-

CIONALIZACIÓN

DEL DERECHO

PROCESAL Y SU

REPERCUSIÓN EN

LA REFORMA DE

LA NORMATIVIDAD

RITUAL (CPP) Y EL

SISTEMA DE

JUSTICIA PENAL

CONSTITUTIO-

NALIZATION OF

ARBITRATION AND

ITS IMPACT IN

STANDARD

LEGISLATION

REFORM, CPP

(CRIMINAL

PROCEDURE

CODE) AND IN

CRIMINAL JUSTICE

SYSTEM 
Para impedir que en la búsqueda y recojo de información probatoria el Estado y sus aparatos de persecución del delito actúen sin freno, impulsados por el afán de eficacia ilimitada y la tiránica justificación que «los resultados mandan y justifican todo», se oponen las siguientes garantías procesales:

n) El derecho a no declarar, a guardar silencio o a la no incriminación $\mathrm{n}^{48}$, que genera para las autoridades que pretendan interrogar a cualquier persona sobre una imputación criminal la obligación de advertirla de la existencia de aquel y que de su ejercicio no se derivará ninguna consecuencia adversa (artículos 8.2.g de la Convención Americana sobre Derechos Humanos y 14.3.g del Pacto Internacional de Derechos Civiles y Políticos).

o) El secreto bancario y la reserva tributaria que solo pueden ser levantados a pedido del juez, del fiscal de la Nación, o de una comisión investigadora del Congreso con arreglo a ley y siempre que se refieran al caso investigado (artículo 2.5 Constitución)

p) La inviolabilidad domiciliar y consiguiente prohibición de ingreso, investigaciones o registros en el domicilio de las personas sin contar con autorización del que lo habita o sin mandato judicial, salvo flagrante delito ${ }^{49}$ o muy grave peligro de su ocurrencia (artículo 2.9 Constitución).

q) El secreto e inviolabilidad de las comunicaciones y documentos privados, incluidas las telecomunicacione $\mathrm{s}^{50} \mathrm{y}$ sus instrumentos, los que pueden ser abiertos, incautados, interceptados o intervenidos por mandato motivado del juez y con las formalidades previstas en la ley (artículo 2.10 Constitución).

48 Apréciese lo mediatizados e imperfectos que resultan a la luz de esta garantía los artículos 127 y 245 del C. de PP.

49 Ver el artículo 4 de la ley 27934 (Intervención del Ministerio Público y de la Policía durante la investigación del delito), del 12 de febrero de 2003, que acuña el concepto de flagrancia reputando su existencia cuando la realización del acto punible es actual y, en esa circunstancia, el autor es descubierto, o cuando el agente es perseguido y detenido inmediatamente después de haber realizado el acto punible o cuando es sorprendido con objetos o huellas que revelan que acaba de ejecutarlo. Este correcto criterio, basado en la inmediatez temporal y personal, propia de la flagrancia delictuosa, fue desnaturalizado por el decreto legislativo 989, que trajo, entre otros, el concepto de flagrancia extensiva hasta por veinticuatro horas cuando media huida y el agente es identificado después de la perpetración del hecho, sea por el agraviado o por otra persona que haya presenciado el hecho, o por medio audiovisual; aunque la ley 29372 corrigió el dislate volviendo a la posición inicial al modificar el artículo 259 (detención policial) del nuevo CPP y disponer su vigencia en todo el país, conjuntamente con el artículo 260 (arresto ciudadano), la ley 29569, del 25 de agosto de 2010, retrocedió a la fórmula fracasada de la flagrancia delictuosa virtual, esto es, extendida hasta por veinticuatro horas, del decreto legislativo 989.

http://www.congreso.gob.pe/ntley/Imagenes/DecretosLegislativos/00989.pdf

http://www.congreso.gob.pe/ntley/lmagenes/Leyes/29372.pdf $\mathrm{http}: / / w w w . c o n g r e s o . g o b . p e / n t l e y / l m a g e n e s / L e y e s / 29569 . p d f$

50 Ver la ley 27697 sobre intervención y control de comunicaciones y documentos privados, del 12 de abril de 2002, modificada por decreto legislativo 991.

http://www.congreso.gob.pe/ntley/lmagenes/Leyes/27697.pdf

http://www.congreso.gob.pe/ntley//magenes/DecretosLegislativos/00991.pdfhttp://www2.ohchr.org/ spanish/law/cat.htm 
r) La prohibición de sustracción e incautación de libros, comprobantes y documentos contables y administrativos, salvo por orden judicial (artículo 2.10, párrafo final Constitución).

s) La terminante prohibición de la violencia moral, psíquica o física, de la tortura y los tratos inhumanos o humillantes ${ }^{51}$ (artículo 2.24.h Constitución).

Estas garantías serían líricas, tinta sobre papel mojado, si su infracción no fuera seguida por la aplicación de la regla de exclusión probatoria que fulmina las consecuencias directas o reflejas de los actos de obtención de pruebas o práctica de medios probatorios que desconozcan o afrenten los derechos fundamentales. Aunque explícitamente la Constitución no menciona esta regla, su contenido aparece considerado cuando indica que «los documentos privados obtenidos con violación de este precepto (secreto e inviolabilidad) no tienen efecto legal» y que «carecen de valor las declaraciones obtenidas por violencia. Quien la emplea incurre en responsabilidad» (artículos 2.10, tercer párrafo y 2.24.h de la Constitución).

\section{I.4.8. Garantías que limitan el uso de la fuerza (coerción) en el proceso penal}

En la marcha del proceso hacia sus objetivos, la elucidación de la verdad material y la determinación y realización, en su caso, de las consecuencias sancionadoras de las normas jurídicas materiales, sobre el agente declarado culpable, es común encontrar situaciones que los obstaculizan. Estas integran el peligro procesal de fuga o elusión de la justicia y el de entorpecimiento de la actividad probatoria

El remedio procesal para estos riesgos se halla en el procedimiento y las medidas cautelares o coercitivas, que representan injerencias más o menos intensas sobre los derechos fundamentales de la persona, sin dejar de ser siempre instrumentales y nunca prejuiciosas decisiones de condena anticipada.

Las medidas coercitivas o provisionales son, desde esta perspectiva, manifestación del empleo de la fuerza dentro del proceso, la que podría desbordarse si no es legitimada y morigerada por requisitos o presupuestos sin los cuales deviene arbitraria como la razonabilidad y proporcionalidad, aplicadas a la resolución de las eventuales necesidades procesales.

Por lo dicho es que, cuando se trata de coerción procesal personal, la ley pone especial cuidado en establecer exigentes requisitos y controles, de

LA CONSTITU-

CIONALIZACIÓN

DEL DERECHO

PROCESAL Y SU

REPERCUSIÓN EN

LA REFORMA DE

LA NORMATIVIDAD

RITUAL (CPP) Y EL

SISTEMA DE

JUSTICIA PENAL

CONSTITUTIO-

NALIZATION OF

ARBITRATION AND

ITS IMPACT IN

STANDARD

LEGISLATION

REFORM, CPP

(CRIMINAL

PROCEDURE

CODE) AND IN

CRIMINAL JUSTICE

SYSTEM 
modo que si la libertad del procesado, favorecido aún por la presunción de inocencia, deba ser afligida con medidas como la prisión preventiva o la comparecencia simple o restrictiva, ello responda estricta y cabalmente a una auténtica necesidad procesal y no configure adelantamiento de sanción o condena.

Bajo determinadas circunstancias, específicamente cuando se buscan pruebas, también es posible usar la fuerza o coerción para restringir derechos fundamentales, como sucede, entre otras medidas, con la videovigilancia, la intervención corporal, la exhibición forzosa e incautación de bienes o el control de comunicaciones y documentos privados, nada de lo cual puede quedar fuera del prolijo cumplimiento de los procedimientos garantizadores establecidos por la ley.

Lo mismo sucede cuando se adoptan medidas como el embargo, enfiladas a evitar el desapoderamiento patrimonial del procesado, con evidente riesgo para el derecho del agraviado de ser resarcido e indemnizado.

La contención de la fuerza en el proceso penal o los impedimentos para evitar se desborde se ven servidos por las siguientes garantías:

t) La aplicación imperativa de los criterios de razonabilidad y proporcionalidad cuando se van a limitar derechos fundamentales (artículo 200 Constitución).

u) La prohibición de restringir la libertad personal, salvo en los casos legalmente previstos, lo que impone el ineludible requisito de legalidad de la coerción y las medidas provisionales, pues su elenco solo puede ser encontrado en la ley (artículo 2.24.b Constitución).

v) La interdicción de la prisión por deudas, lo que no abarca los incumplimientos de deberes alimentarios (artículo 2.2.24.c Constitución).

w)El régimen de la detención, que claramente delimita la detención policial en flagrante delito, ordinario o especial, y el mandamiento judicial, escrito y motivado, de detención (artículo 2.24.f Constitución).

x) El libre tránsito por el territorio nacional y el derecho a salir y entrar en él, salvo las limitaciones impuestas por mandato judicial (artículo 2.11 Constitución).

y) La prohibición de la incomunicación sino resulta indispensable para el esclarecimiento de un delito y, en este caso, siempre que se respete la forma y el tiempo previsto por la ley (artículo 2.24.g Constitución).

z) Elderecho de los reclusos (procesados) de ocupar establecimientos adecuados y el principio de que el régimen penitenciario tiene 
por objeto la reeducación, rehabilitación y reincorporación social (artículo 139.21, 22 Constitución).

\section{SERVICIO DE JUSTICIA Y SUCESIÓN Y PUGNA DE MODELOS PROCESALES}

La manera como las sociedades han atendido los problemas originados por el delito ha sido diversa.

Cada Estado, según la opción política asumida, ha organizado el mecanismo procesal encargado de indagar la ocurrencia de los hechos criminales y establecer las responsabilidades por aquellos. Esta maquinaria, sin embargo, nunca se ha limitado a lo estrictamente procesal; por el contrario, ha sido utilizada para promover y consolidar objetivos políticos coyunturales o imponer una determinada forma de control social, representativa del resguardo de intereses no siempre colectivos sino grupales.

A lo largo de la historia de Occidente, incluyendo los ámbitos territoriales incorporados por la colonización, el proceso penal ha sido configurado según distintos modelos. En ciertos períodos la estructura acusatoria resultaba ser la más funcional y en otros la inquisitiva; esto último, especialmente, cuando urgía concentrar el poder del Estado y evitar cualquier fisura que cuestionara el dominio de los grupos dirigentes.

Analizar la manera como cada modelo procesal identifica sus funciones básicas y las encarga a los correspondientes sujetos que intervienen en él es lo que, a fin de cuentas, permite saber si se está ante un esquema acusatorio o inquisitivo, y también, lo que posibilita establecer el grado de democracia o arbitrariedad procesal instituido. Una vez ha de plantearse que no existe un proceso penal neutro, que siendo muy importante la resolución de los conflictos provocados por el delito esta labor servirá bien a los intereses de la mayoría, o al encubrimiento, promoción y preservación de intereses de facción, por lo que siempre será correcto y legítimo respaldar los modelos compatibles con la defensa de los derechos fundamentales de la persona.

Para calificar un sistema procesal como acusatorio (antiguo o moderno), inquisitivo o mixto (inclinado hacia la primera o segunda opción), hay que seguir las palabras de Eugenio Florián, quien, en su obra Diritto processuale penale (1939, Utet), según cita de Pietro Fredas, sostuvo:

La diversidad en la distribución de las funciones procesales esenciales suministra el criterio para distinguir las dos formas fundamentales del proceso, formas históricas y célebres. Si cada una de estas tres funciones (de acusación, de defensa y de decisión) se confía respectivamente a un órgano propio y separado, que la ejerce y hasta diría que la gestiona, y

LA CONSTITUCIONALIZACIÓN DEL DERECHO PROCESAL Y SU REPERCUSIÓN EN

LA REFORMA DE LA NORMATIVIDAD RITUAL (CPP) Y EL SISTEMA DE JUSTICIA PENAL

CONSTITUTIO-

NALIZATION OF ARBITRATION AND ITS IMPACT IN STANDARD LEGISLATION REFORM, CPP (CRIMINAL PROCEDURE CODE) AND IN CRIMINAL JUSTICE SYSTEM 
así se instituyen tres órganos (acusador, defensor y juez), el proceso es acusatorio. Si estas tres funciones se concentran en poder de una sola persona y se atribuyen a un mismo órgano, que las acumula todas en sus manos, el proceso es inquisitorio. Teniendo que concentrar de modo totalitario las tres funciones en un solo órgano, este no podía ser sino el juez, y así lo fue históricamente. Es decir, en el primer caso el proceso toma la forma acusatoria, y en el segundo, la forma inquisitoria. La forma acusatoria da lugar esencialmente a un proceso de partes y la inquisitoria, a un proceso unilateral de jueces de actividad multiforme, que todo lo absorben y que a todo deben proveer por sí mismos $[\ldots]^{52}$.

Más que perderse en detalles anecdóticos, entonces, el criterio central para identificar un modelo, distinguirlo de los otros y explicar la pugna entre ellos es la configuración específica que cada uno de estos asuma de las funciones procesales indispensables. No en vano, por ejemplo, cuando se revisan los CPP de 1991 y 2004 encontramos una prolija determinación de las tareas del órgano jurisdiccional y demás sujetos procesales (Ministerio Público, imputado-defensor técnico, víctima), a diferencia del C. de PP., que sobredimensiona el papel del juez instructor y subestima las funciones de los otros participantes en el proceso.

Siguiendo la pauta dada por Florián, enseguida se efectuará sucinta referencia a los modelos procesales históricamente configurados, teniendo en cuenta la forma como este fenómeno se ha manifestado en el ámbito nacional, porque este conocimiento contribuirá a explicar mejor por qué la reforma procesal ha dejado de ser un simple cambio normativo para representar la transformación ineludible de todo el sistema o servicio de justicia penal.

\section{II.1. Inquisitorial}

Las principales notas de este modelo, como sostiene Maier, a quien en adelante se sigue ${ }^{53}$, son las siguientes: (i) la potestad de administrar justicia no emana del pueblo sino de los jerarcas, o tiranos que controlan el poder estatal, quienes concretan su abusiva autoridad a través de una estructura de funcionarios etiquetada con el membrete de «órganos judiciales»; (ii) las funciones de persecución del delito y de juzgamiento y fallo se confunden, asignándoselas al mismo sujeto procesal, surgiendo, entonces, la figura del investigador-juez decidor o gran inquisidor; (iii) el acusado carece de la condición de sujeto y ve reducida su condición a objeto, sus posibilidades de defensa son mínimas o inexistentes, en cambio las cortapisas que se le oponen son muchas, todas enfiladas a

52 FLORIÁN, Eugenio. De las pruebas penales. Tomo I: «De la prueba en general». Bogotá: Temis, 1990, p. 6.

53 MAIER, Julio. B. J. Derecho procesal penal. Tomo I. «Fundamentos». Segunda edición. Buenos Aires: Editores del Puerto S.R.L., 1996, pp. 259-264 y 442-460. 
debilitarlo y alcanzar su confesión; (iv) la forma del procedimiento y el estilo de trabajo de los operadores son los del secreto o la reserva irracional y de la escritura, manifiesta en el expediente; (v) la valoración de la prueba se rige por el sistema legal que tarifa o asigna valor antelado a cada medio probatorio, precedido por actuaciones, abiertamente denigratorias y horrorosas como la tortura, justificadas con el argumento de búsqueda de la verdad a cualquier precio, de ahí lo emblemático de la confesión como la reina de las pruebas, y (vi) el fallo, en la aplastante mayoría de casos, no hace más que confirmar los prejuicios del inquisidor y aplacar los reclamos de la presunción de culpabilidad.

En la medida en que los Estados occidentales autoritarios requirieron concentrar al máximo el poder político, el procedimiento inquisitivo alcanzó carta de ciudadanía y expansión, refinando sus prepotentes técnicas, como se ve en el manual procesal penal confeccionado para este propósito por los dominicos Sprenger y Kramer, entre 1485 y 1486, llamado Malleus Maleficarum o El martillo de los brujos ${ }^{54}$.

En el Perú, una vez producida la conquista e instituida la Colonia, el procedimiento criminal que se impuso fue el inquisitivo, característico de la España colonialista ${ }^{55}$. Durante el período prehispánico ${ }^{56}$ la justicia penal fue la correspondiente a un sistema señorial, draconiano y hasta mágico, pronto sustituido ${ }^{57}$ por las normas y usos judiciales de la metrópoli. Así fue como se instaló y operó por largo tiempo la inquisición, acerca de la cual da puntual cuenta don Ricardo Palma ${ }^{58}$ :

El Tribunal de la Inquisición de Lima (se sujetaba) á fórmulas y prácticas jurídicas. Así, en los procesos se encuentran la sumaria, la compurgación canónica, la declaración indagatoria, el plenario, las posiciones, la publicación de testigos, la tacha, el careo, la calificación, censura o dictamen que un teólogo daba sobre los puntos de acusación, y aun era permitido el recurso de fuerza al rey. Pero, para hacer este sistema judicial bárbaro y defectuoso, bastaba con el secreto empleado en la sustanciación de los juicios, y con el tormento que se aplicaba cuando el reo permanecía inconfeso [...]. El tormento se aplicaba con la siguiente sentencia:

Christo nomine invocato. Fallamos, atentos los autos y méritos del proceso y sospechas que de él resultan contra el reo, que le debemos condenar

54 Kramer, Heinrich y Jacobus Sprengler. Malleus Maleficarum. El martillo de los brujos. Barcelona: Círculo Latino, 2005.

55 Ver: Leyes de las Indias. Libros Primero-Nono.

http://www.congreso.gob.pe/ntley/LeyIndiaP.htm

56 VARGAS, Javier. El derecho penal en el Imperio de los Incas (Contribución al estudio de la Historia del Derecho peruano). Lima: Atlántida, 1981.

57 BASADRE, G. Jorge. Historia del derecho peruano. Lima: Edigraf, 1986.

58 PALMA, Ricardo. Anales de la Inquisición de Lima. Lima: Congreso de la República del Perú, 1997, pp. 58-59.

LA CONSTITU-

CIONALIZACIÓN

DEL DERECHO

PROCESAL Y SU

REPERCUSIÓN EN

LA REFORMA DE

LA NORMATIVIDAD

RITUAL (CPP) Y EL

SISTEMA DE

JUSTICIA PENAL

CONSTITUTIO-

NALIZATION OF

ARBITRATION AND

ITS IMPACT IN

STANDARD

LEGISLATION

REFORM, CPP

(CRIMINAL

PROCEDURE

CODE) AND IN

CRIMINAL JUSTICE

SYSTEM 
y condenado á que sea puesto en cuestión de tormento, en la cual mandamos esté y persevere tanto tiempo cuando á Nos bien visto fuere, para que en él diga la verdad dé lo que está testificado y acusado; con protestación que le hacemos que si en dicho tormento muriese, ó fuere lisiado, ó se siguiese mutilación de miembro o efusión de sangre, sea á su culpa y cargo, y no á la nuestra, y por no haber querido decir la verdad.

Cuando se esperaba que la emancipación e independencia, al instaurar el sistema republicano, inaugurarían también un sistema de justicia penal democrático según los propósitos sanmartinianos («Las bases de la Constitución» $)^{59}$, en el cual las causas criminales se resolviesen mediante juzgamiento público y reconocimiento y declaración del hecho delictuoso por jurados y aplicación de la ley por jueces independientes e inamovibles, la situación se mantuvo invariable, con fuerte supervivencia del procedimiento inquisitivo —adversario de la democracia, como trasunta en el Código de Procedimientos en Materia Penal de 1863 , aprobado en $1862^{60}$ — sostenido por una estructura que privilegia el secreto, la escritura y proscribe la oralidad en sus dos etapas: el sumario y el plenario.

\subsection{Mixto}

Con la gran Revolución francesa de 1789 no solo cayó el antiguo régimen feudal autoritario: también claudicó su funcional mecanismo procesal penal inquisitivo, el cual fue reemplazado por el modelo mixto, que mantuvo algunas notas del pretérito esquema durante la fase de investigación y abrió sus puertas a la publicidad del acusatorio en la etapa del juzgamiento.

Esta opción llegó tardíamente al Perú y encontró asiento en el Código de Procedimientos en Materia Criminal 192061, así como en el aún vigente Código de Procedimientos Penales de $1939^{62}$. Lamentablemente, la inclinación de uno y otro no fue idéntica, ya que el primero - pergeñado por Ángel G. Cornejo, partidario de la instauración de los jurados- osciló más hacia el acusatorio, mientras que el segundo —obra de Zavala Loayza— no pudo escapar

59 BASADRE G., Jorge. Historia de la República del Perú 1822-1933. Séptima edición, corregida y aumentada, Tomo I. Lima: Editorial Universitaria, 1983, pp. 12-13.

60 De Trazegnies Granda, Fernando. La idea de Derecho en el Perú republicano del siglo XIX. Lima: Fondo Editorial de la PUCP, 1980, p. 162.

RAMOS NúNEEZ, Carlos. Historia del derecho civil peruano. Siglos XIX y XX. Tomo IV, «Legislación, abogados y exegetas». Lima: Fondo Editorial de la PUCP, 2003, pp. 28, 276-283.

61 CALLE, Juan José. Código de procedimientos en materia criminal. Promulgado por el Poder Ejecutivo el 2 de enero de 1920.

Ley 4019, de 24 de diciembre de 1919.

CORNEJO, Mariano H. Novísimo código de procedimiento en materia criminal. Lima: Imprenta Torres Aguirre, 1920, pp. III-XLVIII (Exposición de motivos).

62 Villavicencio, Víctor Modesto. Derecho Procesal Penal. De conformidad con el Código de Procedimientos Penales del Perú., Lima, 1965. 
de la impronta inquisitiva, como se nota por la sobreestimación de la instrucción en detrimento del juzgamiento, y del juez instructor en perjuicio de los demás sujetos procesales. Algo parecido ocurre con las numerosas leyes procesales penales especiales que han profundizado la distorsión inquisitorial, como el decreto legislativo 124, que ni siquiera guarda las formas mixtas, y que al generalizarse, ofende la garantía de juicio previo, público y oral.

\section{II.3. Acusatorio antiguo y contemporáneo}

Tanto el acusatorio antiguo como el moderno comparten, mutatis mutandi, las siguientes virtudes: (i) la potestad de administrar justicia emana del pueblo y se ejerce a través de un Poder Judicial independiente e imparcial; (ii) la persecución del delito, en cuanto a investigación y acusación se refiere está a cargo de un órgano civil autónomo, el Ministerio Público; (iii) el procesado es un sujeto y no objeto procesal que goza de la presunción de inocencia y del derecho de defensa; (iv) el procedimiento es sustancialmente público, oral y contradictorio, rigiendo en él, además, la igualdad de armas; (v) la valoración de la prueba no es tasada sino libre y debe ir precedida por actuaciones legítimas que no violen derechos fundamentales, repudiándose el prejuicio y destacándose, en cambio, la objetiva imparcialidad, y (vi) la declaración de culpabilidad la emite el jurado o el juez, quien, en su caso, absuelve o condena, dosificando con justicia la sanción.

En el Perú, gracias al movimiento de reforma, guiado por las bases constitucionales (1979) de un programa penal democrático, se plantea la primera propuesta integral acusatoria con el CPP de 1991, ulteriormente mejorado en sus versiones de 1995 y 1997. Las dificultades que este código afrontó, permaneciendo en vacatiolegis hasta hoy (salvo veintidós artículos), demuestran el enorme poder de las fuerzas retardatarias que han visto en él un sistema transparente y justo, contrario a sus tradicionales intereses manipuladores de la justicia penal, alejada del pueblo y sometida a sus ofensores.

Hoy, que se cuenta con la versión acusatoria renovada de 2004 (CPP, decreto legislativo 957), no resta más que confirmar que la reforma se ha consolidado en lo normativo, aun cuando subsisten dudas sobre la posibilidad de su implementación y de cambio radical de la cultura inquisidora que acompaña desde siglos a los operadores del sistema y, cómo no, también a los voceros de la llamada «opinión pública», los medios de comunicación masiva —enceguecidos promotores de la tolerancia cero- - y el endurecimiento punitivo.

Quienes piensen que la reforma y su código encontrarán un camino real, amplio y descansado deben desechar cuanto antes esta idea optimista 
pero infundada: la historia mundial y peruana han demostrado que eso no es posible, siempre la sucesión de un esquema procesal por otro tiene raíces sociales profundas que expresan la solución de determinada pugna de intereses entre los que se han valido de los mecanismos de control social para perpetuar sus privilegios y los que han entendido que el tratamiento procesal del delito y sus agentes solo adquiere legitimidad cuando se hace en defensa de los derechos fundamentales de la persona, bajo cánones republicanos, democráticos, propios de un Estado de derecho. No se tiene al frente, entonces, un horizonte pacífico sino de confrontación entre sistemas procesales, que se resiste a morir y que pugna por asentarse. En esta pugna no cabe neutralidad: cada actor del sistema de justicia penal habrá de optar, no desentenderse, asumir un compromiso y actuar en consecuencia.

\section{ACERCAMIENTO AL TÍTULO PRELIMINAR DEL CPP}

El CPP no es neutro, tampoco es creación de académicos diletantes; intenta, en cambio, responder a la manifiesta necesidad de superar la crisis crónica del servicio de justicia penal.

Esta propuesta normativa, ofrecida por el movimiento de reforma procesal penal, se caracteriza por sus marcadas cualidades acusatorias, garantizadoras, de tendencia adversativa, eficaz y eficiente, en tanto modelo que busca diferenciarse y superar las opciones inquisitivas y mixtas, estancadas en la rutina burocrática y el estilo de trabajo improductivo basado en la escritura y el culto al expediente.

La adhesión del CPP al programa que, para lo procesal, estipula la Constitución, aparece de modo nítido en cada uno de los diez artículos de su Título Preliminar. Aquí se examinan estos solo panorámicamente porque cada uno de ellos daría pie a un tratamiento más profundo.

Sin desconocer el surgimiento de numerosos problemas que acarreará la implementación y aplicación progresivas del CPP, se confirma que la única manera de afrontarlos satisfactoriamente será asiendo firmemente los principios y garantías procesales penales que componen la opción republicana y democrática.

\section{III.1.Opción acusatoria, garantizadora, de tendencia adversativa, eficaz y eficiente}

Para caracterizar el modelo que trae el CPP, como en su oportunidad se hizo con el código de 1991 y sus versiones mejoradas de 1995 y 1997, se recurre al calificativo de acusatorio, debido a que al revisar el tratamiento dado a las funciones procesales básicas se aprecia que el nuevo texto efectúa una determinación perfectamente diferenciada, 
primero, de la persecución, comprensiva de la investigación, acusación y prueba; segundo, de la defensa o resistencia ante la incriminación, y por último, del juzgamiento y fallo. Es más, junto a esta determinación de funciones el código procede a atribuirlas al respectivo sujeto procesal, entiéndase el Ministerio Público, el imputado y su defensor técnico, y el órgano jurisdiccional, respectivamente (artículos 1, 60, 61, referidos al Ministerio Público; 71, 80, 84, alusivos al imputado y su defensor técnico, y 16 relativo al órgano jurisdiccional), distinguiéndose así de las opciones inquisitivas o mixtas que confunden o superponen las funciones precitadas y sobredimensionan el rol de un sujeto procesal como el juez, postergando a los otros.

En la determinación de las cualidades del nuevo modelo también se hace referencia al término garantizador o «garantista», porque el código entroniza un tipo de proceso que integra de modo redoblado garantías procesales o escudos protectores del justiciable, quien no por estar sujeto a imputación pierde la condición de o se torna indigno (artículo 71). De este modo se distancia de las posiciones inquisitivas o mixtas, para las cuales — de manera explícita o sobreentendida- el imputado es solo objeto al servicio del proceso que, por ejemplo, puede permanecer indefinidamente bajo prisión preventiva, encerrado o arrumbado como una fiera o cosa.

Además de la nominación de acusatorio y garantizador, se afirma que el CPP es de tendencia adversativa porque remarca la naturaleza principal del juicio público y oral, la trascendencia del contradictorio y la responsabilidad que en materia de actuación probatoria corresponde a las partes que sostienen pretensiones contrarias: el Ministerio Público como titular de la pretensión punitiva, y el imputado y su defensor técnico a cargo de la pretensión libertaria. Gracias a esta nota adversativa se crean las condiciones para que el órgano jurisdiccional cumpla, durante la investigación, función de garante de los derechos fundamentales, y en la etapa intermedia, de saneamiento, en tanto que en el juicio se ocupará, sobre todo, de evaluar imparcialmente el resultado de la actividad probatoria realizada por las partes y emitir fallo de absolución o condena (artículos 356.1, 385.2, 29.2 , 4, 5; 71.4, 253.1, 323, 393, 394, 398 y 399). En clara divergencia con los modelos inquisitivos o mixtos, se aprecia que el CPP no enturbia la imparcialidad del juez involucrándolo en actividades de investigación o pesquisa o atribuyéndole la tarea de probar los hechos.

El nuevo proceso, además, se reclama eficaz y eficiente porque instaura la autoevaluación a través de los logros alcanzados, cuantitativa y cualitativamente, y se abre a la crítica de sus usuarios. Al superar la tara del trámite y la rutina burocrática, el proceso surgido de la reforma y sus actores no admiten satisfacción, sino alcanzan,

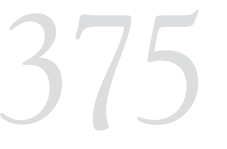

LA CONSTITU-

CIONALIZACIÓN

DEL DERECHO

PROCESAL Y SU

REPERCUSIÓN EN

LA REFORMA DE

LA NORMATIVIDAD

RITUAL (CPP) Y EL

SISTEMA DE

JUSTICIA PENAL

CONSTITUTIO-

NALIZATION OF

ARBITRATION AND

ITS IMPACT IN

STANDARD

LEGISLATION

REFORM, CPP

(CRIMINAL

PROCEDURE

CODE) AND IN

CRIMINAL JUSTICE

SYSTEM 
pronto y cumplidamente, recurriendo a la simplificación procesal o a salidas alternativas y conclusiones anticipadas de causas que superen la sobrecarga de los despachos, la resolución o redefinición de los conflictos generados por el delito, entendido esto como atención de los requerimientos sociales de paz, tranquilidad y seguridad de los intereses de las víctimas de los hechos punibles, y de los derechos y garantías de los imputados, sin cohonestar impunidad ni errores judiciales.

\section{III.2. Principios acogidos}

Aunque llama la atención que el Título Preliminar del CPP no lleve el nombre de «Principios generales» $\mathrm{O}$ «Principios fundamentales», como en el CP vigente y el CPP de 1991, esto no autoriza concluir que sus pautas modélicas, estructurales y de interpretación no estén recogidas en tan importante apartado, colocado precisamente en el frontis de todo este cuerpo normativo para confirmar su adhesión al programa procesal penal de la Constitución y la tarea concreta de desarrollarlo.

Lo anterior explica por qué en el Título Preliminar encontramos directas referencias a las garantías procesales penales propias de un mecanismo de resolución de conflictos democrático, garantizador y eficaz.

El artículo I.1 del rubro bajo estudio estatuye de modo sintético el principio de jurisdiccionalidad, al indicar que la justicia penal es impartida exclusivamente por los órganos judiciales y que tan delicada función destaca por su consustancial característica de imparcialidad, esto es, de sujeción a la Constitución y la ley, y de operatoria en un plazo razonable, contrario a cualquier dilación indebida.

Este mismo artículo I, en su inciso 2, confirma la trascendencia que el nuevo modelo le da al juicio previo, el que no confunde con cualquier otra etapa procesal sino relieva al indicar las peculiaridades del juzgamiento oral, público y contradictorio. Puede decirse, entonces, que para el CPP toda la actividad procesal gira en torno a la preparación y realización del juicio, por lo que las otras etapas habrán de organizarse no porque importen o se justifiquen por sí, sino siempre desde la óptica de la fase central o decisoria que es el juzgamiento (artículo 356.1).

En el inciso 3 de la norma I se reconoce a las partes el derecho a la igualdad, de manera tal que estas puedan ejercer plenamente las facultades que la Constitución y el código estipulan a su favor, constituyendo una novedad muy interesante que este inciso afirme el deber judicial de allanar cualquier obstáculo, incluso originado por razones objetivas atribuibles a las diferencias económicas o sociales de las partes, que impidan o dificulten la vigencia de la igualdad procesal. Así se confirma la vieja exigencia de «igualdad de armas» entre los sujetos procesales 
que contienden, litigan y sostienen pretensiones adversas, aun cuando uno de ellos — como el Ministerio Público— sea oficial, y el otro —el imputado_- particular.

El numeral 4 del artículo I consagra el derecho al recurso o a la impugnación, frente a sentencias y autos de sobreseimiento que pongan fin a la instancia. De esta manera se asegura la existencia de un recurso ordinario: la apelación penal (artículos 404, 413), que permita el cuestionamiento de lo decidido en materia de hechos y de derecho, esto es, integral, por un superior revisor.

En el inciso 5 del artículo I, desde la opción procesal que asume un compromiso cierto con la dignidad humana, se establece la obligación estatal de garantizar la indemnización por los errores judiciales, sentándose las bases para superar el actual estado de cosas en esta materia, regulada por la ley $24973^{63}$, del 28 de diciembre de 1988, cuya ineficacia es palmaria cuando se aprecia la ejecutoria del casi fantasmal Fondo Nacional Indemnizatorio de Errores Judiciales y Detenciones Arbitrarias.

El inciso 1 del artículo I consigna el derecho cuyo contenido confirma que la justicia penal es gratuita. Esta ubicación no parece ser la más sistemática, pues lo coloca delante del conjunto de los grandes principios procesales, cuando se trata, más bien, de un elemento promotor de la igualdad que, en tal contexto y no fuera o por encima de él, debe ser entendido. Este derecho, además, sufre una importante matización cuando se anota que no incluye el pago de costas procesales (artículo 497), instituto sobre el cual se tienen insignificantes referencias o antecedentes nacionales, puesto que el C. de PP. y el CPP 91 carecen de notas al respecto. Ha de señalarse, sin embargo, que de la regla de pago de costas están eximidos el Ministerio Público, entre otros organismos, y sus representantes (artículo 499.1), y que, en cuanto a los demás sujetos procesales vencidos, el órgano jurisdiccional, atendiendo a la serias y fundadas razones que los hayan llevado a promover o intervenir en el proceso, puede eximirlos de soportar esa carga.

A la presunción de inocencia, el Título Preliminar le asigna su artículo II. El inciso 1 de este dispone que todo imputado sea considerado inocente y tratado como tal, en tanto no se pruebe lo contrario y se declare su responsabilidad mediante sentencia firme y motivada. Esa sentencia - agrega la norma - ha de edificarse sobre suficiente actividad probatoria de cargo, obtenida y actuada con las debidas garantías procesales. Destaca que, cuando media duda sobre la responsabilidad penal, ha de resolverse a favor del imputado. En suma, para desvirtuar la presunción de inocencia, a través de una sentencia

LA CONSTITUCIONALIZACIÓN DEL DERECHO PROCESAL Y SU REPERCUSIÓN EN LA REFORMA DE LA NORMATIVIDAD RITUAL (CPP) Y EL SISTEMA DE JUSTICIA PENAL

CONSTITUTIONALIZATION OF ARBITRATION AND ITS IMPACT IN STANDARD LEGISLATION REFORM, CPP (CRIMINAL PROCEDURE CODE) AND IN CRIMINAL JUSTICE SYSTEM 
condenatoria, se requerirá que: (i) la carga material de la prueba, en relación con los hechos constitutivos de la pretensión penal, haya sido promovida y actuada por la parte acusadora y no por la defensa; (ii) la prueba se practique en juicio oral y bajo inmediación del órgano jurisdiccional sentenciador; (iii) los actos de prueba no sean confundidos con los atestados policiales u otros actos de investigación; (iv) los jueces no funden su sentencia en prueba prohibida o ilícita; (v) las sentencias de condena no se soporten exclusivamente sobre la declaración de coimputados, y (vi) los jueces cumplan con la obligación de razonar la prueba y la expliciten al motivar su fallo ${ }^{64}$. Queda claro, entonces, que a nadie puede imponérsele condena si durante el proceso, a través de la actividad probatoria, legítima, idónea y fehaciente, no se establece su responsabilidad más allá de cualquier duda razonable.

El inciso 2 del artículo II, como derivación de la presunción de inocencia, prohíbe que funcionario o autoridad policial alguna presente como culpable a una persona, no condenada por sentencia firme, o brinde información en tal sentido. Nadie que conozca el morboso espectáculo mediático que se regodea presentando a imputados o procesados como si fuesen culpables o reos rematados negará la importancia de acuñar una garantía como la descrita y promover su pleno respeto ${ }^{65}$.

El artículo III estatuye la garantía ne bis in idem de forma completa, ya que acoge su significado material referido a la proscripción de doble sanción por un mismo hecho punible, lo que la relaciona con la cosa juzgada, y también sus implicancias procesales, prohibiendo la doble persecución, sucesiva o simultánea por lo mismo, siempre, además, que se exista idéntico sujeto e igual fundamento.

En el entendido de que la potestad sancionadora del Estado es única, aunque bien pueda adquirir perfiles administrativos o penales, y que aquel tiene una sola oportunidad para hacer valer su pretensión punitiva, el Título Preliminar dice que la interdicción de la persecución múltiple rige también para las sanciones penales y administrativas, en cuanto es inaceptable que por el mismo hecho estas se acumulen. De ahí que, para evitar superposiciones perjudiciales al imputado, regle que el derecho penal tiene preeminencia sobre el derecho administrativo.

Una manifestación de lo dicho se encuentra en el inciso 6 de la Segunda Disposición Modificatoria y Derogatoria del CPP, que dispone que el

64 Gimeno SendRA, Vicente. La prueba prohibida. Separata. Conferencias Magistrales, Lima, 6 y 7 de abril de 2006, Instituto de Ciencia Procesal Penal, pp. 1-5.

$65 \mathrm{El}$ decreto supremo 01-95-JUS, del 6 de enero de 1995, prohíbe la presentación pública de detenidos; sin embargo, en el sonado caso de Joran van der Sloot -joven holandés imputado por asesinato-, la Policía, sin que el fiscal hiciera algo por corregir el despropósito, exhibió al detenido ante los medios de comunicación como si fuera una fiera o trofeo de guerra. Ver: El Comercio, p a6, y Perú.21, p. 14, de 6 de junio de 2010. La norma de la referencia fue infelizmente derogada por el decreto supremo 005-2012-JUS, del 23 de febrero de 2012. 
artículo 8 del decreto legislativo $813^{66}$ (Ley Penal Tributaria, del 20 de abril de 1996), relativo a la investigación y promoción de la acción penal en los delitos tributarios, queda redactado de modo que la administración deba comunicar al fiscal los indicios de la comisión de delito tributario descubiertos en el curso de sus actuaciones, que el fiscal, en razón de este aviso y en coordinación con el Órgano Administrador del Tributo, disponga lo conveniente, que ordene a la administración ejecutar ciertas diligencias o las realice por sí mismo, y que, en cualquier momento, disponga que dicho órgano le remita todo lo actuado en el estado que se encuentre, prosiguiendo la pesquisa en Fiscalía o por la Policía.

Consecuente con la tradición liberal, en este mismo artículo el CPP exceptúa de los efectos del ne bis in idem los casos de revisión de sentencias condenatorias, que se canalizan a través de la acción correspondiente cuando luego de la condena o imposición de medida de seguridad es dictada otra sentencia contra persona distinta del primer sancionado y ambas resoluciones son inconciliables, de lo que resulta la prueba de inocencia del primigenio condenado. Otro tanto ocurre cuando la sentencia se emite contra una precedente que es cosa juzgada; asimismo, si se demuestra que un elemento de prueba decisivo en la sentencia, es falso, inválido, adulterado o falsificado, o luego de la sentencia se descubran nuevos hechos o medios de prueba capaces de establecer la inocencia del condenado. También, si se acredita que la sentencia fue producto de un delito cometido por el juez o grave amenaza contra él o sus familiares, siempre que en tales hechos no haya intervenido el condenado, y cuando la norma que sustentó la condena fuese declarada inconstitucional por el Tribunal Constitucional o inaplicable en un caso concreto por la Corte Suprema (artículo 439).

Para decantarse de los modelos inquisitivo y mixto, el CPP hace precisiones sobre la función asignada al Ministerio Público. El inciso 1 del Artículo IV indica, para esto, que le corresponde la titularidad del ejercicio público de la acción, esto es, que solo a él, en la medida en que tiene calidad de órgano civil autónomo de persecución del delito y sus agentes, le corresponde poner en marcha la maquinaria judicial para la apropiada determinación y realización de la pretensión punitiva. Esta tarea persecutoria, en consecuencia, implica investigar, acusar y probar la acusación, en manifiesto cumplimiento de la carga probatoria que la distingue.

Sin embargo, ha de recordarse que el Ministerio Público no es el abogado de la víctima sino de la sociedad, y que por ello sus actividades las somete al estricto principio de objetividad. No indaga, pues, para acusar de cualquier manera y en todos los casos, sino para descubrir 
la verdad de los hechos. De ahí que la información probatoria que recoja no tenga que ver únicamente con la responsabilidad del imputado sino también, en su caso, con la inocencia o no culpabilidad de aquel. Siendo el Ministerio Público el único ente autorizado para requerir la actuación judicial con respecto a los delitos de persecución oficial, y por tanto responsable de obtener del órgano jurisdiccional condenas que materialicen las consecuencias punitivas de la norma penal, deviene obvio reconocerle papel conductor y contralor jurídico de los actos de investigación que practica la Policía, quien cumple tarea operativa y función de policía judicial al servicio del Ministerio Público (inciso 2 del artículo IV).

El inciso 3 del artículo IV es un canon explícito diferencial de los actos de investigación realizados por el Ministerio Público o la Policía y los denominados actos jurisdiccionales. No existe entre ellos sinonimia, puesto que emanan de órganos diferentes, con atribuciones y funciones distintas, por lo que cuando sea necesaria una decisión de naturaleza jurisdiccional, el Ministerio Público la requerirá, expresando las razones de su pedido, del órgano judicial.

Para asegurar la estructura acusatoria del proceso, el artículo V, inciso 1, perfila las atribuciones y competencias funcionales de los jueces, atribuyéndoles, como luego se detalla al normarse el proceso común (Libro tercero), la dirección de la fase intermedia y, sobre todo, del juzgamiento, así como la compleja tarea de expedir resoluciones que resuelvan las incidencias de la causa y sentencias que le pongan fin. Es garantía para cualquier persona - dice el inciso 2 del numeral examinado- de que la pena o medida de seguridad que se le imponga lo sea por el órgano judicial determinado por ley, con lo que se ratifica que el derecho penal se aplica única y exclusivamente por los juzgados y tribunales y solo mediante el proceso, lo que deriva de un triple monopolio: uno, el de la exclusividad estatal en la determinación de las conductas que son delito y de las penas que las conminan, con lo que se proscribe la autotutela y la justicia privada; dos, el de la concreción aplicativa del derecho penal solo por los órganos judiciales, no legislativos, ni administrativos, y tres, el de la exclusividad procesal, en cuanto el proceso es el medio para asegurar la legalidad del resultado final de la causa y los derechos del acusado ${ }^{67}$.

De las medidas limitativas de derechos se ocupa el artículo VI multilateralmente, al referir sus notas esenciales y presupuestos. Según este dispositivo, la coerción se atiene a las medidas previstas en la Ley Suprema y su imposición requiere modo y forma legales, además de la concurrencia de garantías. La limitación de derechos

67 Montero ArocA, Juan. Principios del proceso penal. Una explicación basada en la razón. Valencia: Tirant lo Blanch, 1997. 
no se impartirá de oficio, sino siempre a petición de parte legitimada, requiriendo intervención judicial y dictado de resolución motivada, con suficiente base indiciaria o elementos de convicción y auténtica necesidad procesal, respetando las exigencias de la razonabilidad. El grado de injerencia que implique una medida limitativa dependerá, asimismo, de la ponderación que, recurriendo al criterio de proporcionalidad, se realice según la naturaleza y propósito de la medida, y la envergadura del derecho fundamental afectado.

Por lo expuesto, para el CPP la libertad del imputado es la regla y la prisión preventiva una excepción que de ningún modo puede ser asumida fuera de sus notas instrumentales y constituir adelantamiento de condena.

Ninguno de los motivos que respaldan el empleo de la coerción durante el proceso, como la búsqueda de pruebas, la conjura del peligro procesal de fuga o entorpecimiento de la actividad probatoria y la garantía de la indemnización de la víctima ante el riesgo de desapoderamiento patrimonial del imputado, contradicen lo precedente: la naturaleza operacional, nunca de fondo, de las medidas limitativas de derechos.

Superando el silencio que guarda el C. de PP., el artículo VII, incisos 1 y 2 , del nuevo cuerpo ritual regula la vigencia temporal de la ley procesal penal, en el sentido de que esta es de aplicación inmediata, incluso cuando se trata de procesos en trámite. Esto quiere decir que la norma procesal aplicable será siempre la que esté vigente en el momento de realización del acto procesal, a diferencia de lo que ocurre en el campo del derecho penal material, en el cual la norma aplicable es la que estuvo vigente cuando se cometió el delito. El principio de aplicación inmediata de la norma procesal se atempera y admite, sin embargo, algún matiz de flexibilidad, como la referida a la aplicación ultractiva de la ley anterior cuando se trata de medios impugnativos ya interpuestos, actos procesales con principio de ejecución y plazos ya iniciados. También se admite la retroactividad benigna de la ley procesal más favorable a los derechos individuales del imputado, dictada con posterioridad a la actuación procesal, así se trate de actos concluidos.

Por su lado, los incisos 3 y 4 de este artículo VII establecen pautas básicas de interpretación de las normas adjetivas, sobre todo de las que coactan la libertad o restringen el ejercicio de derechos procesales, limitan un poder conferido a las partes o estipulan sanciones rituales, en el sentido que la interpretación debe ser restrictiva: quedan prohibidas la extensiva y la analogía, salvo que sean pro imputado o pro ejercicio de sus derechos, y que cuando existe duda insalvable sobre la ley aplicable deba optarse, también, por la más favorable al procesado. 
El artículo VIII, en sus tres incisos, resume lo que el CPP entiende como legitimidad de la prueba, consideración que prescribe que los únicos medios de prueba que pueden componer el acervo probatorio y, por ello, ser valorados, son los obtenidos e incorporados a la causa por un procedimiento constitucionalmente legítimo. El exigente filtro, previsto para asegurar lo precitado, es la regla de exclusión probatoria según la cual no tienen efecto legal las pruebas conseguidas con violación de los derechos fundamentales de la persona (artículo 159). Al respecto, conviene detenerse y observar que el artículo bajo comentario menciona que esa obtención ilegítima de pruebas puede ser directa o indirecta, lo que abre juego a la admisión de la teoría del fruto del árbol envenenado o de los efectos reflejos de la prueba ilícita.

Ha de repararse, también, que la norma dice violación del «contenido esencial» de los derechos fundamentales, lo que permite deducir que la regla de exclusión probatoria admita excepciones como las sustentadas en la «buena fe» del operador, la «infracción beneficiosa para el imputado», la «eficacia de la prueba ilícita con respecto a terceros» o personas distintas al titular del derecho afectado, la «ponderación de intereses», la fuente independiente, el descubrimiento inevitable, la «destrucción de la mentira del imputado» y la del «actuar a propio riesgo», como ocurre cuando alguien hace revelaciones voluntarias sobre un delito o acerca de actividades relacionadas con esta clase de hechos ante un interlocutor que lo graba sin su conocimiento ${ }^{68}$.

Demostrando su concepción garantizadora, el CPP, en su artículo IX, incisos 1 a 3, insiste en cada una de las manifestaciones del derecho de defensa, estipulando que a todo imputado debe informársele de sus derechos y, en forma detallada y de inmediato, de la incriminación que pesa contra él. Precisa, además, que el imputado tiene derecho inviolable e irrestricto a ser asistido por un abogado defensor de su elección o de oficio desde que es citado o detenido, a contar con tiempo suficiente para preparar su defensa, ejercitar su defensa material, participar con igualdad de armas en la actividad probatoria y usar los medios probatorios pertinentes. En el mismo sentido, este numeral del Título Preliminar prohíbe que el imputado sea obligado o inducido a reconocer culpabilidad, a incriminarse o incriminar a sus familiares, estipulaciones estas que encuentran sustento en el horizonte de la presunción de inocencia ya mencionado.

Según las tendencias procesales más avanzadas, el CPP dedica especial atención a la víctima del delito para evitar perjudicarla doblemente con los avatares o secuelas de la causa, de modo que (inciso 3) le asegura

68 Ver el Acta de la sesión del Pleno Jurisdiccional Superior Nacional Penal: «Problemática en la aplicación de la norma penal, procesal y penitenciaria». Trujillo, 11 de diciembre de 2004 . Acuerdos Plenarios. Tema 3: La prueba ilícita y la prueba prohibida. 
los derechos de información y participación procesal y establece la obligación oficial de protegerla y darle trato apropiado. Esto explica la tesitura procesal asumida en lo referente a la víctima por los artículos 94 y siguientes del código. Así, por ejemplo, cuando se indica que tiene derecho, entre otros, a ser informada del resultado del procedimiento aun cuando no haya intervenido en él, a ser escuchada antes de cada decisión que implique la extinción o suspensión de la acción penal, a recibir un trato digno y ser protegida, y a impugnar el sobreseimiento y la sentencia absolutoria (artículo 95.1). Lo propio hace cuando norma que en los delitos que afectan intereses colectivos — es decir, que lesionan a un número indeterminado de personas-o en crímenes internacionales, se considera como agraviados a las asociaciones vinculadas directamente con esos intereses, siempre que estén reconocidas e inscritas antes de la comisión del delito (artículo 94.4).

El artículo X, que cierra el Título Preliminar, afirma el valor expansivo de las normas que lo integran al estatuir que prevalecen sobre cualquier otro canon del código y que deben utilizarse como fundamento de interpretación. El siguiente ejemplo ayudará a entender el sentido de la norma comentada. El artículo 370, al determinar la ubicación de las partes en la audiencia, precisa que el juez penal tiene al frente al acusado, a su derecha al fiscal y abogado del actor civil, y a su izquierda al abogado defensor del acusado. Visto el asunto, podría decirse que se reproduce la distribución del viejo sistema: la cruz inquisitiva que el modelo mixto no se ha atrevido a desterrar; cruz que aísla al acusado de su defensor y lo coloca solitario en el centro, obstaculizando su participación en la estrategia de defensa a la luz de lo aprecie en el proceso. Pues bien, en un auténtico juicio público, oral y de tendencia adversativa como el que quiere el Título Preliminar del CPP, la distribución de las partes en la sala de audiencias debe permitir la comunicación plena y permanente del acusado con su defensor técnico (artículo 371.3), lo que implica se encuentren uno al lado del otro, juntos, no separados. Esto exige cambiar la distribución actual, para colocar frente al juez (centro y centro izquierda) al imputado y su abogado defensor, y al lado derecho, también frente al juez, al fiscal y la parte civil y su defensa. Así es como debe interpretarse el artículo 370 si se es consecuente con los principios y el modelo innovador del CPP. No en vano, desde julio de 2006, en que este novísimo conjunto de cánones empezó a regir a plenitud en Huaura, y luego en varios otros distritos judiciales más, la ubicación de los sujetos procesales en la Sala de Audiencias se ha democratizado cancelando la cruz inquisitorial, resabio medieval. 


\section{III.3. Principios y problemas de implementación y regencia progresivas del CPP}

Se equivocan los que piensan que el CPP es una creación que se agota en la búsqueda de modernidad o mejoramiento normativo, estimulada por la preocupación de algunos bien intencionados o ilusos profesores; al contrario, el nuevo sistema procesal es la respuesta más completa que se ha dado al estado de crisis permanente del servicio. Se trata, entonces, de una propuesta para salir del estancamiento que deslegitima cada vez más la actuación oficial de la justicia penal y sus operadores. La crisis a enfrentar es muy compleja, como lo dejan ver sus síntomas más evidentes: por un lado, se tiene el descontento de la colectividad y los agraviados, su intranquilidad e inseguridad ante la falta de oportuno procesamiento y sanción, cuando corresponda, de los delitos, de sus prácticas violentas, y el nulo resarcimiento por los daños que estos ocasionan, y por el otro, se expande el fenómeno de los presos sin condena, sometidos a causas que no se resuelven en plazo razonable. Internamente las cosas no se ven mejores, porque los despachos fiscales y judiciales padecen y se sofocan tras el enorme peso de la sobrecarga procesal.

En un estado de cosas como el descrito, y dado el primer paso consistente en establecer en el ámbito normativo un nuevo modelo procesal penal, lo que toca hacer es asegurar su implementación o puesta en marcha eficaz y eficiente. No debe cederse ante la posición simplemente operacional que imagina que los problemas se resolverán con más presupuesto o mayor número de fiscales, jueces y abogados públicos, porque esas mejoras, siempre indispensables, se diluirán en la medida que no se les dé sólido cimiento y claro norte, aportados por los principios analizados.

Cuando los actores del sistema asuman como propios los objetivos de la reforma, conozcan y comprendan la lógica del modelo y la estructura que trae el CPP; cuando se percaten de que es necesario, incluso, cambiar la ideología, cultura y estilos de trabajo de la justicia penal tradicional, burocrática y escrita, entonces recién será posible abrigar la esperanza de consolidar la marcha de un mecanismo procesal compatible con los requerimientos constitucionales y los tratados sobre derechos humanos.

Siendo que la implementación del CPP es progresiva (decreto legislativo 958$)^{69}$ —esto es, su vigencia avanza de distrito judicial en distrito judicial, no simultáneamente en todo el país—, podría surgir un problema digno de ser debatido con rigor. Se trata del reclamo que los procesados de los distritos judiciales donde el código aún no opera integralmente (Lima, Lima Sur, Lima Norte, Callao, Junín, Huancavelica, Ayacucho y Apurímac) pudiesen hacer, sosteniendo que las diferencias o ubicaciones geográficas diversas no tienen por qué 
afectarlos y privarlos de los beneficios y bondades del nuevo mecanismo procesal penal que ya disfrutan otros incriminados. Esto en la medida que el CPP rige a plenitud en los distritos judiciales de Huaura (1 de julio de 2006), La Libertad (1 de abril de 2007), Tacna y Moquegua (1 de abril de 2008), Arequipa (1 de octubre de 2008), Tumbes, Piura y Lambayeque (1 de abril de 2009), Cusco, Puno y Madre de Dios (1 de octubre de 2009), Ica y Cañete (1 de diciembre de 2009), San Martín, Amazonas y Cajamarca (1 de abril de 2010), Ancash, Santa, Pasco y Huánuco (1 de junio de 2012) y Ucayali y Loreto (1 de octubre de 2012 $)^{70}$.

Este problema, que a primera vista parece irresoluble, será atendido debidamente si a tal reclamo se responde con la indicación de que, si bien el código se aplica progresivamente, esto no significa que en el resto de distritos judiciales el servicio se imparta de espaldas a la Constitución. Se trata, en consecuencia, de atender todos los casos penales, en uno u otro lugar del país, según las pautas de la Ley Suprema, reinterpretando cualquier norma, hasta la más imperfecta, bajo la óptica y las exigencias del programa procesal penal constitucional. Así ocurre en los casos que atiende la Sala Penal Nacional, con sede en Lima.

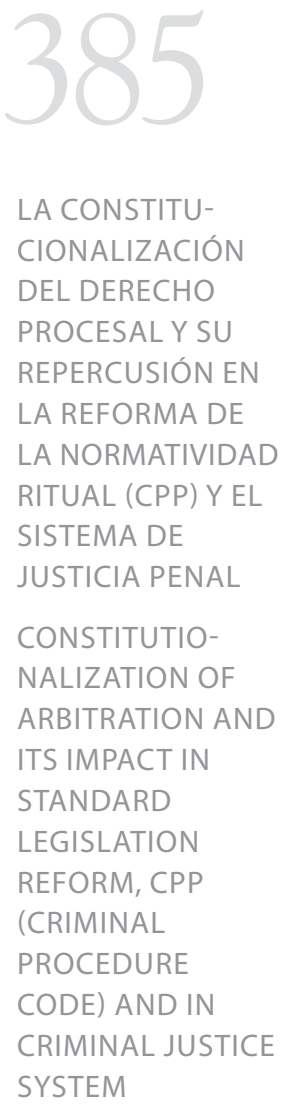

70 Ver los decretos supremos 007-2006-JUS (4.03.06), 005-2007-JUS (5.05.07), 016-2009-JUS, (21.11.09), 016-2010-JUS (30.09.10), 004-2011-JUS (31.05.11) y 019-2012-JUS (20.12.12) que actualizan o modifican el Calendario Oficial de Aplicación Progresiva del Código Procesal Penal (decreto supremo 013-2005-JUS - 08.10.05), y establecen, entre otros asuntos, la regencia total del nuevo ordenamiento en los distritos judiciales de Callao, Lima Norte, Lima Sur y Lima el 1 de diciembre de 2014.

En este escenario de implementación y aplicación progresivas, considérese la trascendencia de la ley 29574, aprobada por el Congreso, en el pleno del 10 de junio de 2010, y publicada el 17 de septiembre de 2010, así como su modificatoria, ley 29648, del 1 de enero de 2011, que dispone la vigencia integral del CPP en todo el país para el tratamiento de determinados delitos contra la administración pública, con la siguiente secuencia: Lima, 15 de enero, Lima Norte y Callao, 1 de abril, y los demás distritos judiciales, 1 de junio de 2011.

Ver: http://www.mpfn.gob.pe/ncpp/files/16285b_DS\%20007-2006-JUS.pdf

http://www.justiciaviva.org.pe/webpanel/doc_int/doc26112009-125508.pdf

http://www.mpfn.gob.pe/ncpp/files/69d774_016-2010-minjus.pdf

http://www2.congreso.gob.pe/Sicr/TraDocEstProc/CLProLey2006.nsf

http://www.congreso.gob.pe/ntley/lmagenes/Leyes/29574.pdf

http://www.congreso.gob.pe/ntley/lmagenes/Leyes/29648.pdf 